\title{
GIS-Based Hydrological Modelling in the Toronto Region
}

By

\author{
RUIQIU LI, B.Sc. \\ Heibei Normal University, Shijiazhuang, China, 1997
}

\begin{abstract}
A Project Report
Presented to the School of Graduate Studies in

Partial Fulfillment of the Requirements for the

Degree of Master of Engineering in the

Program of Civil Engineering at Ryerson University
\end{abstract}

Toronto, Ontario, Canada, 2005

(C) Ruiqiu Li 2005 


\title{
UMI Number: EC53045
}

\author{
All rights reserved \\ INFORMATION TO USERS
}

The quality of this reproduction is dependent upon the quality of the copy submitted. Broken or indistinct print, colored or poor quality illustrations and photographs, print bleed-through, substandard margins, and improper alignment can adversely affect reproduction.

In the unlikely event that the author did not send a complete manuscript and there are missing pages, these will be noted. Also, if unauthorized copyright material had to be removed, a note will indicate the deletion.

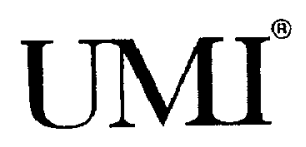

\section{UMI Microform EC53045 \\ Copyright 2008 by ProQuest LLC}

All rights reserved. This microform edition is protected against unauthorized copying under Title 17, United States Code.

ProQuest LLC

789 East Eisenhower Parkway

P.O. Box 1346

Ann Arbor, MI 48106-1346 


\title{
DECLARATION
}

I, Ruiqiu Li, hereby declare that I am the sole author of this report.

I authorize Ryerson University to lend this report to other institutions or individuals for the purpose of scholarly research.

\author{
Ruiqiu Li \\ Department of Civil Engineering \\ Ryerson University
}

I further authorize Ryerson University to reproduce this report by photocopying or by other means, in total or in part, at the request of other institutions or individuals for the purpose of scholarly research.

\section{Ruiqiu Li \\ Department of Civil Engineering \\ Ryerson University}


Ryerson University requires the signature of all persons using or photocopying this report. Please sign below, and give address and date.

\begin{tabular}{|c|c|c|c|}
\hline Name of Borrowers & Date & Address & Signature \\
\hline & & & \\
\hline & & & \\
\hline & & & \\
\hline & & & \\
\hline & & & \\
\hline & & & \\
\hline & & & \\
\hline & & & \\
\hline & & & \\
\hline & & & \\
\hline & & & \\
\hline & & & \\
\hline & & & \\
\hline & & & \\
\hline & & & \\
\hline & & & \\
\hline & & & \\
\hline & & & \\
\hline & & & \\
\hline & & & \\
\hline
\end{tabular}




\title{
GIS-Based Hydrological Modelling in the Toronto Region
}

\begin{abstract}
The urbanization changes a watershed's response to precipitation. The most common effects include the reduced infiltration and the decreased travel time, which significantly increase runoff and peak discharges. This study attempts to analyze the impact of land use on runoff in the Toronto Region. In this report, the focus is on two aspects: (1) generating watershed boundaries using digital elevation model (DEM) data with the help of HEC-HMS, and (2) calculating runoff in the the study area using the United States Soil Conservation Service (SCS) curve number method for the early 1990s and 2003.
\end{abstract}

The study is based on the watershed boundaries generated from DEM data with $10 \mathrm{~m}$ resolution. Because of the flat surface in the south of the Toronto Region, the areas of the watersheds generated in this study are slightly less than the real ones, but the difference is within acceptable range.

As a crucial parameter in the SCS method for runoff calculation, curve number is difficult to obtain. In this project, the curve numbers for each watershed are calculated by using the land cover and soil data of the early 1990s and 2003 respectively. According to the theory, the higher the curve number is, the higher the potential of runoff generation in the area is. Unlike what is expected, the curve numbers have changed little from the early 1990s to 2003, although the impervious surface has increased. This is because the variation of the land cover is too little to increase the curve numbers. The curve number 
for each watershed is a weighted one. If the area of a specific lot which has changed from pervious to impervious surface is small, the weight variation of such area is also small. The other reason for the little change of curve numbers is that the land cover data sets of the early 1990s and 2003 used different classification systems. To eliminate the discrepancy resulting from those land cover classification systems, the curve numbers in 2003 were calculated by referring both classification schemes of the early 1990 s and 2003. Because the land cover classification in this study is reasonable, the curve number of the Toronto Region in 2003, 80.4 can be used in the future research. 


\section{ACKNOWLEDGEMENTS}

First of all, I would like to thank my supervisor, Professor Dr. Jonathan Li, for his kind guidance and good ideas. Special thanks for all of his fruitful discussions, invaluable suggestions and critical remarks. I would also like to thank him for understanding me of selecting my preferred study area and study program. His serious and significant research has a great influence on my work.

I also attribute my accomplishments to Professor Dr. Songnian Li. Whenever I asked help from him, he always lent me a hand immediately. I would like to thank other faculty and staff members in the Department of Civil Engineering and the Department of Geography, for their encouragement and instructions. Many thanks are also given to Leah Stanwyk for her administrative support, and Desmond Rogan for his technical assistance about the GIS software.

I would also like to acknowledge all my fellow graduate students in Ryerson University, who have helped me in various ways and made the study period enjoyable, in particular, Hongmei Zhao, Yu Li, Lijun Gu, and Paul Du. A special thank is extended to Dr. Xiangyun $\mathrm{Hu}$ and Dr. Yong Hu in York University, for their all sorts of help. I would like to express my gratitude to Mr. Don Haley and Mr. Chris Benjamin of TRCA, who provided me a lot of crucial data and constructive suggestions. Many thanks are given to my friend Dr. George Sparrow, who has paid close attention to my study and gave me a lot of unselfish help. 
Financial support partially provided by the School of Graduate Studies is gratefully acknowledged.

Last, but not least, I want to express my sincere appreciation to my parents and parentsin-law, siblings and siblings-in-law, who provided unwavering support and understanding, and to my beloved husband, Weidong $\mathrm{Wu}$, for his love, patience, and encouragement. They are the wind under my wings. 


\section{TABLE OF CONTENTS}

DECLARATION ...................................................................................................................... ii

BORROWER'S PAGE.............................................................................................................. iii

ABSTRACT ........................................................................................................................ iv

ACKNOWLEDGEMENTS ..................................................................................................... vi

TABLE OF CONTENTS ................................................................................................ viii

LIST OF FIGURES ............................................................................................................... $x$

LIST OF TABLES .................................................................................................................... xi

LIST OF ABBREVIATIONS ................................................................................................. xii

Chapter 1 INTRODUCTION ................................................................................................. 1

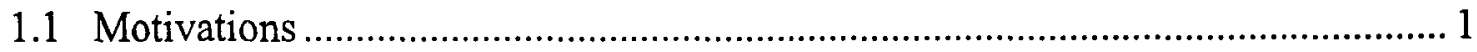

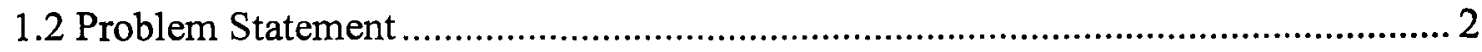

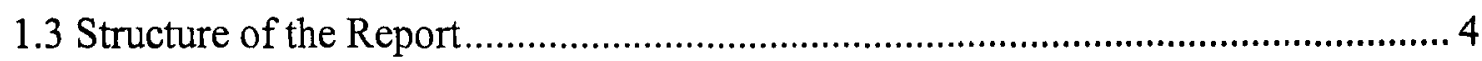

Chapter 2 LITERATURE REVIEW ........................................................................ 6

2.1 DEM Application in Hydrological Analysis........................................................... 6

2.1.1 Hydrological Applications ............................................................................. 7

2.1.2 Two Types of DEM in Delineation of Watershed Boundaries.......................... 8

2.1.3 Algorithms for Watershed Delineation........................................................... 11

2.1.4 Effect of DEM Resolution on the Watershed Delineation.............................. 13

2.1.5 Problems with Flat Areas......................................................................... 14

2.2 Integration of GIS with Hydrological Modelling ……......................................... 15

2.2.1 GIS and Hydrological Model Coupling Method ............................................ 16

2.2.2 Limitations of GIS in Hydrological Modelling ............................................ 18

2.3 Calculation of Runoff in Urban Areas .................................................................. 20

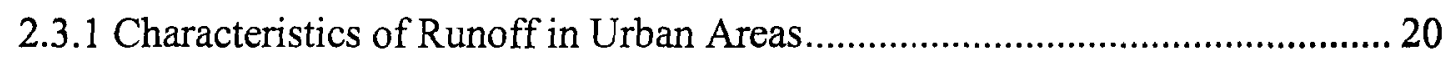

2.3.2 SCS Curve Number Method ......................................................................... 21

Chapter 3 METHODOLOGY ................................................................................................. 23

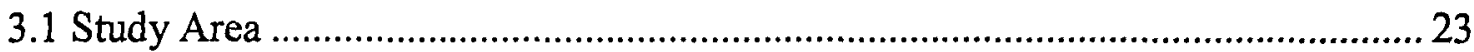

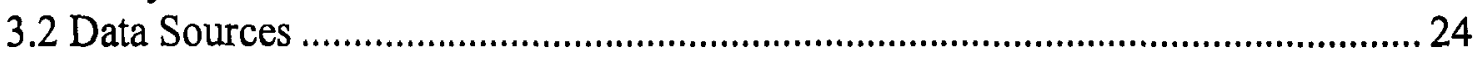

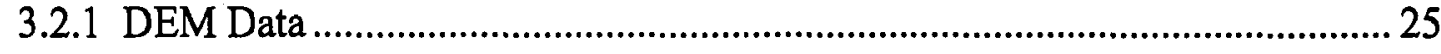

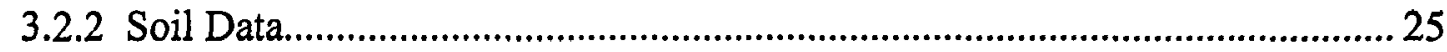




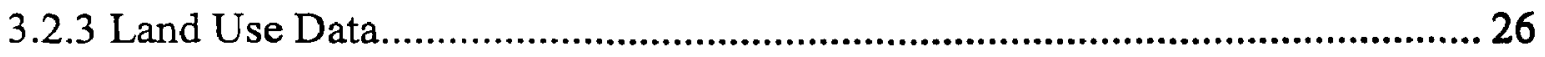

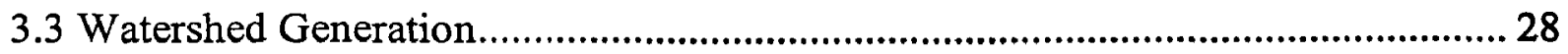

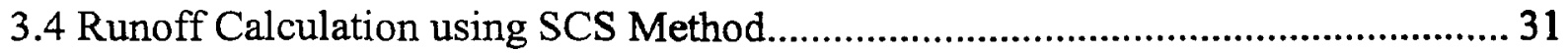

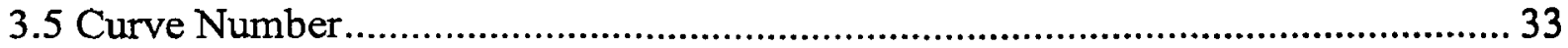

3.5.1 Hydrological Soil Groups ......................................................................... 33

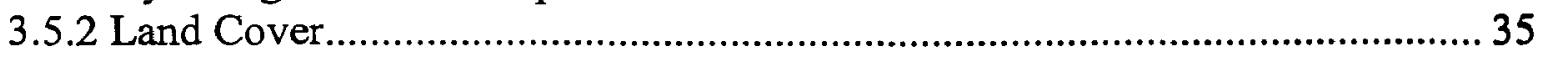

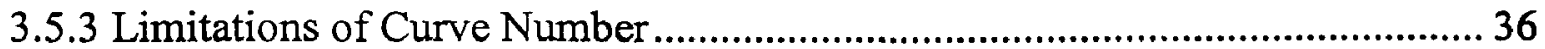

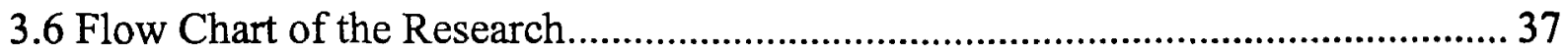

Chapter 4 RESULTS AND DISCUSSION ................................................................. 39

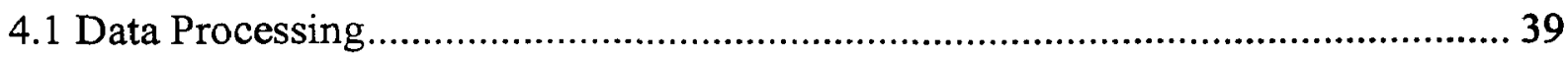

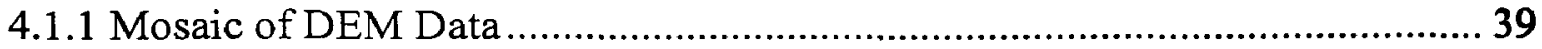

4.1.2 Watershed Generation.................................................................................... 41

4.1.3 Coding Soil Data According to HSG Scheme ................................................. 41

4.1.4 Coding Land Cover Data According to TR55 ................................................ 43

4.2 Watershed boundaries in the Toronto Region ..................................................... 45

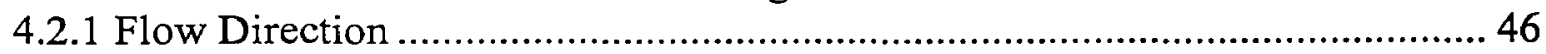

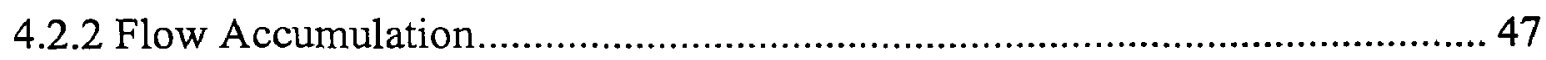

4.2.3 Watershed Boundaries and Streams within Toronto Region........................... 48

4.2.4 Accuracy Analysis ...................................................................................... 48

4.3 Comparing the Land Cover Effect on Runoff in the early 1990s with 2003 .......... 51

4.4 Curve Number in the Study Area.....................................................................5

Chapter 5 CONCLUSIONS AND RECOMMENDATIONS .......................................... 61

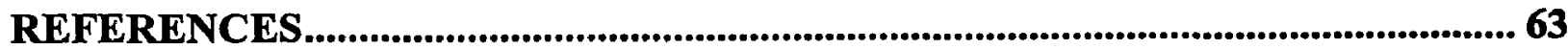




\section{LIST OF FIGURES}

Figure 3.1 Conservation authority of the Toronto Region h............ 24

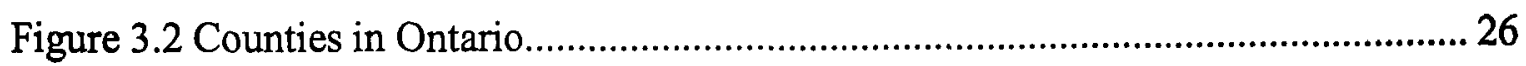

Figure 3.3 Land cover of the Toronto Region in 2003 .................................................. 27

Figure 3.4 Land cover of the Toronto Region in the early 1990 s..................................... 28

Figure 3.5 The flow directions defined in the HEC-HMS.............................................. 30

Figure 3.6 The flow chart of the research progress ........................................................ 38

Figure 4.1 DEM tile index in Toronto watershed ......................................................... 40

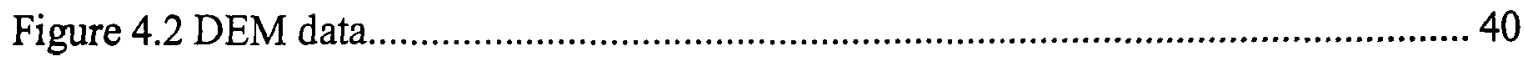

Figure 4.3 3D visualization generated from the TIN .................................................... 41

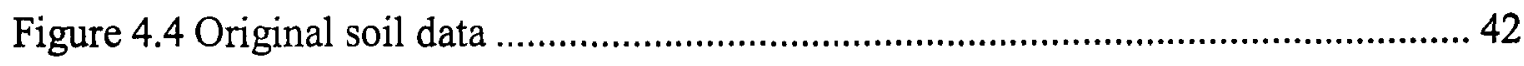

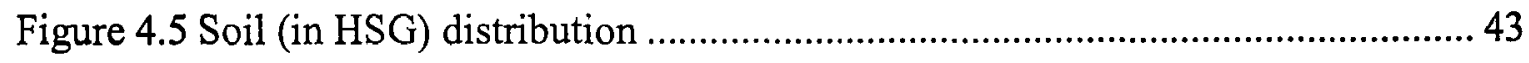

Figure 4.6 Land cover (early 1990s) classified according to the TR55........................... 45

Figure 4.7 Land cover (2003) classified according to the TR55 ..................................... 45

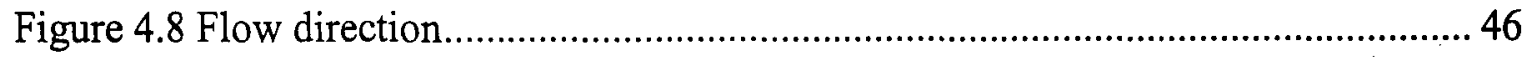

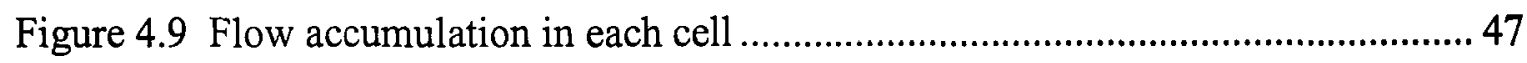

Figure 4.10 Watersheds in the Toronto Region ......................................................... 48

Figure 4.11 Watersheds in Toronto (From TRCA, 2004 ) .............................................. 49

Figure 4.12 Curve numbers ( (a) in the early 1990s (b) in 2003) ..................................5 52

Figure 4.13 Curve numbers of each watershed.............................................................52

Figure 4.14 The relationship among rainfall, runoff and curve number........................... 54

Figure 4.15 Land cover of each watershed in 2003 ...................................................... 56

Figure 4.16 Land cover classified based on the information of early 1990s and 2003 .... 59

Figure 4.17 Curve numbers in the Toronto Region (2003) .............................................6 60 


\section{LIST OF TABLES}

Table 2.1 The main advantages and disadvantages of TnN and grid ............................ 10

Table 3.1 Mapping Information of DEM data ...................................................... 25

Table 3.2 Function of each step in terrain processing .......................................... 29

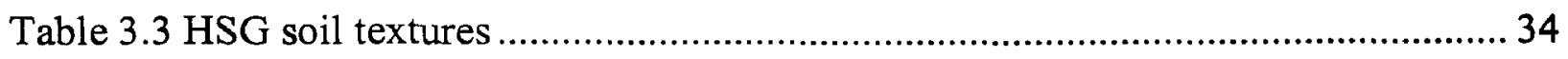

Table 3.4 Curve number definitions in the TR-55 ................................................ 35

Table 4.1 Conversion of land cover (early 1990s) according to the TR55 standard ....... 44

Table 4.2 Conversion of land cover (2003) according to the TR55 standard................ 44

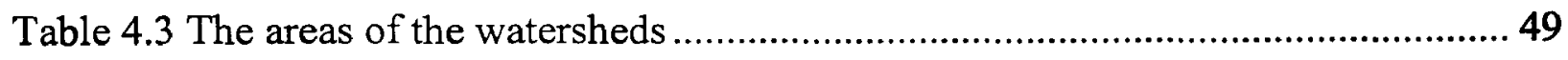

Table 4.4 Correlations between the paired area samples ........................................ 50

Table 4.5 t-test of the paired area samples ...................................................... 50

Table 4.6 Correlations between the paired curve number samples .............................53

Table 4.7 t-test of the paired curve number samples ............................................ 53

Table 4.8 Comparison of the curve numbers and runoffs between early 1990s and 2003

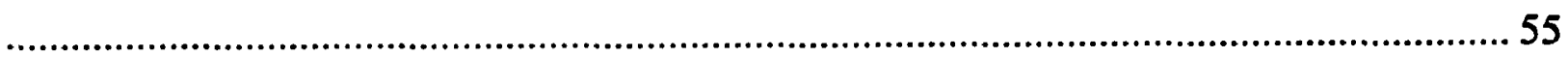

Table 4.9 Classification of the land cover based on the TR-55 ................................. 58 


\section{LIST OF ABBREVIATIONS}

\begin{tabular}{ll} 
AAFC & Agriculture and Agri-food Canada \\
AOC & Area of Concern \\
CN & Curve Number \\
DEM & Digital Elevation Models \\
ESRI & Environmental Systems Research Institute \\
GIS & Geographic Information Systems \\
GTA & Greater Toronto Area \\
HEC & Hydrologic Engineering Centre \\
HMS & Hydrologic Modeling System \\
HSG & Hydrologic Soil Groups \\
NSDB & National Soil DataBase \\
SCS & Soil Conservation Service \\
TIN & Triangulated Irregular Network \\
TM & Thematic Mapper \\
TR-55 & Technical Release 55 \\
TRCA & Toronto and Region Conservation Authority \\
& \\
\hline
\end{tabular}





\section{Chapter 1}

\section{INTRODUCTION}

\subsection{Motivations}

Under the urbanization trend, land cover in urban watersheds has been changing from pervious to impervious surface little by little. The change results in the variation of the watershed storage characteristics and the hydrological response. It also reduces the nature interception, depression storages and the potential for water to infiltrate. Because of the reduced potential for infiltration, the volume of surface runoff will also increase as a watershed becomes urbanized (Marshall, 1990). As a result, urbanization increases the risk of flood. Furthermore, the urbanization causes more pollution. Some of the pollutants can dissolve in the runoff. As the polluted water flows downhill or seeps into groundwater, the pollutants discharged to the upstream segments worsen the quality of the water in the downstream segments of the same river system. Polluted water discharged from the downstream sources combines with municipal wastewater and the effects are cumulative.

The hydrological studies to determine runoff of an area should be based on long-term stationary streamflow records. Such records are seldom available for small drainage areas. Even when they are available, accurate statistical analysis of the data is usually impossible because of the urbanization during the period when the data were recorded. 
Therefore it is necessary to estimate peak discharges and runoff with hydrological models based on measurable parameters.

Hydrologic data analysis and modeling using Geographic Information Systems (GIS) are now rapidly growing. Firstly, considering the spatial feature of watershed parameters and precipitation controlling the hydrological processes, it is not surprising that GIS has become an integral part of hydrological studies. Vieux (2001) noted that the GIS maps describing topography, land use and land cover, soils, and meteorological variables may become model parameters or inputs in the simulation of hydrological processes.

Secondly, for ground water management, watersheds are considered to be the most practical unit since impacts are felt at the watershed level, rather than at the level of administrative boundaries, such as municipalities (Environment Ontario, 2004). The development of computer techniques, manual survey of watershed boundary has been gradually replaced by the GIS based watershed. Grid and Triangulated Irregular Network (TIN) DEMs (Digital Elevation Models) are the most suitable data structures used in the delineation of watershed boundaries.

\subsection{Problem Statement}

As one of the fastest growing large urban regions in Canada, the Greater Toronto Area (GTA) has extended by $10 \%$ in average and the population has increased more than 450,000 since 1996 . Over the next 30 years, the GTA is projected to grow by more than 2.6 million people, reaching 7.45 million by 2031 . With the dream of owning a single 
family home, young families are drawn to the communities springing up throughout the outer regions of the GTA (Urban Development Services Department, Toronto, 2003).

In such an urban setting, population increase has a direct influence on the land use, then on the hydrological parameters. In a natural condition where there is a lot of grass or vegetation, the stormwater is usually not a problem, because the rain filters into the ground. However, for a modern city like Toronto, where much land is covered by concrete, asphalt, brick, and the ways by which water picks up and travels to the sewer have changed, a lot of stormwater runs off roofs, roads and parking lots, trickles down through drain pipes, and empties into stormwater grates. Once the water enters the grates (having collected dirt, oil, grease and a lot of other pollutants along the way), it travels through the extensive storm sewer system $-4,500 \mathrm{~km}$ in all in the city of Toronto - to some 2,600 outfalls or outlet pipes. In some cases, stormwater mixes with wastewater in the combined sewers or infiltrates into sanitary sewers. This causes the wastewater system and the City's sewage treatment plants overloaded, and untreated water enters the rivers, streams and Lake Ontario (City of Toronto website, 2004). As a result, water quality will be degraded in those water bodies from the environmental and physical perspectives, and the environment around those water bodies will also be affected, for example the beaches.

The purpose of this report is to extract the hydrological characteristics of watersheds in the Toronto Region from the DEM data. Combined with other spatial data, those hydrological parameters are used to calculate the runoffs for different years. The basic 
idea behind obtaining the runoffs is that the changes of the runoffs can reflect the impact of land use change on urban hydrology.

\subsection{Structure of the Report}

The overall scope of this study is to apply spatial data and GIS tools to hydrological modeling in the Toronto Region. The main work focuses on the watershed generation and runoff calculation. This study does not attempt to examine the reliability of GIS-based hydrological models, but rather employs a common accepted spatial hydrological model.

This report consists of six chapters. It is delineated as follows.

Chapter 1 addresses the necessity and the importance of using spatial data for hydrological modelling. It gives a brief description of the problem and overall objectives followed by a summary of the report structure.

Chapter 2 summarizes the status of DEM application in hydrological analysis and the integration of GIS with hydrological modelling. It also provides a review of the United States Soil Conservation Service (SCS) curve number method for urban runoff calculation. 
Chapter 3 describes the methodology applied in this study. Topics reviewed in this chapter include the data sources, process of watershed boundaries generation, the CSC method and the TR-55 guide.

Chapter 4 presents how the data were processed. It also provides a comprehensive discussion of the results and their accuracy. The finial watershed boundaries and curve numbers of 2003, which are the key factors for runoff calculation, are presented.

Chapter 5 draws conclusions and makes recommendations according to the results of the study. 


\section{Chapter 2}

\section{LITERATURE REVIEW}

The influence of surface morphology on catchment hydrology and the impact of slope, aspect and horizon shading on insolation probably represent the most important operating controls at toposcales (Wilson and Gallant, 2000). Many popular topographic attributes can be derived from DEM. In the first part of this chapter, the DEM application in the hydrology, its principles and the limitations are described. The second part of this chapter is about how GIS, an efficient tool, couples spatial data with hydrological models. Then SCS curve number method, one hydrological model commonly used in GIS, is introduced.

\subsection{DEM Application in Hydrological Analysis}

Although the hydrological models are once sufficient to model catchment outflow, it is now necessary to estimate distributed surface and subsurface flow characteristics, such as flow depth and flow velocity (Moore et al.,1991). Numerous studies have shown that the shape of the land surface can affect the lateral migration and accumulation of water, sediments, and other constituents (e.g., Moore et al., 1998). Reliable estimation of topographical parameters reflecting terrain geometry is necessary for geomorphological, hydrological and ecological studies, because terrain controls runoff, erosion, and sedimentation (Vieux, 2001). As mentioned above, DEMs are commonly used data sources for topographic attributes extraction. 
A DEM consists of an ordered array of numbers representing the spatial distribution of elevation above some arbitrary datum in a landscape (Moore et al., 1993). Attributes that are computed directly from the DEM are called primary attributes. While secondary or compound attributes involve combinations of primary attributes and constitute physically based or empirically derived indices that can characterize the spatial variability of specific processes occurring on the landscape. Primary attributes include slope, aspect, plan and profile curvature, flow-path length, and upslope contributing area. Most of these topographic attributes can be calculated from the directional derivatives of a topographic surface (Wilson and Gallant, 2000).

Slope of the ground surface is a key factor in the overland flow process and hydrologically very important in small basins where it may be the dominant factor in determining hydrograph shape. The influence of the slope is most relevant to indices of peak flow and hydrograph shape. Furthermore, for any soil map, slope information is a must. The shape of the basin also affects the characteristics of lag time in the hydrograph, the time of rise, and the peak flow rate. Given the pear like shape of the watershed, the time of rise in a hydrograph will be later than normal allowing for a longer lag time. Channel network patterns express the shape of a hydrograph as well (Brady, et al., 2001).

\subsubsection{Hydrological Applications}

There have been many applications of DEM and its derivatives in hydrological practice (Meijerink et al., 1994). Some hydrological models use DEM derivatives, such as 
answers model (Beasley et al., 1982), agricultural non point simulation model (Young, 1987) and the model used by Chairat and Delleur (1993).

The availability of DEM also offers new opportunities to estimate spatial evapotranspiration (Romanovicz et al., 1993), to yield the spatial distribution of unsaturated thickness by substracting the topographic surface and the groundwater surface, and to generate a map showing effective duration of sunshine in shadowed terrain (Meijerink et al., 1994), etc.

While DEMs provide the benefit of computer-based analysis, they also offer the equally important ability to view 3D perspective (Maune, 2001). Sight is an important sense for human beings because people generally derive a great deal of information through the vision and the uncanny ability to "see" relationships and patterns. DEMs make it easy to focus on a particular aspect of the terrain and do not hide the patterns which people are searching for behind unrelated noises. Moreover, certain applications benefit from a high degree of realism. People who are not trained to read maps may easily understanding them if terrain information is included. Alternatively, a 3D perspective with data overlain on top of a terrain model can improve the understanding of the problem.

\subsubsection{Two Types of DEM in Delineation of Watershed Boundaries}

Watersheds have been utilized as a basic unit in water resource analysis because they contain components that are interrelated and can be viewed as a single interactive ecological system. A watershed is defined as a catchment basin, which is delineated 
topographically and drained by a stream system; it is a hydrological unit used for planning and management of water resources.

When choosing a method to present a surface, it is important to consider its end use. The ideal structure for a DEM may be different when it is used for a distributed hydrological model or to determine the topographic attributes of the landscape. Grid DEMs and TIN are the primary data structures used in the delineation of watershed boundaries.

Grid is commonly used to represent the hydrological data because DEMs are often stored in this format. This is an important data source also because of the vast amounts of data available. Gird is one of the most widely used data structures because it can be easily treated by computer algorithms. However, grid has several disadvantages when used in the hydrological modelling (Vieux, 2001):

- Grid can not easily handle abrupt changes in elevation.

- The size of grid mesh affects the results and the computation efficiency.

- The computed upslope flow paths used in hydrological analysis tend to zig-zag and are therefore somewhat unrealistic.

- The definition of specific catchment areas may be imprecise in flat areas.

A triangular irregular network (TIN) is an irregular network of triangles which represents a surface as a set of non-overlapping contiguous triangular facets of irregular sizes and shapes. TINs are more efficient when representing the surface than the uniformly dense grid representation. 
TINs have become increasingly popular because of their efficiency in storing data and their simple data structure for accommodating irregularly spaced elevation data. Advantages have also been found when TIN models are used in inter-visibility analysis on topographic surfaces, extraction of hydrological terrain features and other applications. A TIN has several distinct advantages over the contour and raster representations of surfaces. The primary advantage is that the size of each triangle may be varied so that broad flat areas are covered with a few large triangles, while highly variable or steeply sloping areas are covered with many smaller triangles. It makes the TIN more efficient than the grid structure since the elements in a TIN may vary in size according to the variability of the surface.

Further comparision between grid and TIN is shown in the Table 2.1 (ET Spatial Techniques,2004; Goodchild, 2001;).

Table 2.1 The main advantages and disadvantages of TIN and grid

\begin{tabular}{|l|l|l|}
\hline & \multicolumn{1}{|c|}{ TIN } & \multicolumn{1}{c|}{ Grid } \\
\hline Advantages & $\begin{array}{l}\text { - Ability to describe the surface at } \\
\text { different level of resolution } \\
\text { - Efficiency in storing data } \\
\text { - Triangles can be rendered quickly } \\
\text { by graphics processors }\end{array}$ & $\begin{array}{l}\text { - More data exist } \\
\text { - Easy to store and manipulate } \\
\text { - Smoother, more natural } \\
\text { appearance of derived terrain } \\
\text { features } \\
\text { Many applications require } \\
\text { uniform-sized spatial objects }\end{array}$ \\
\hline Disadvantages & $\begin{array}{l}\text { - In many cases require visual } \\
\text { inspection and manual control of } \\
\text { the network }\end{array}$ & $\begin{array}{l}\text { - Inability to use various grid } \\
\text { sizes to reflect areas of } \\
\text { different complexity of relief. }\end{array}$ \\
\hline
\end{tabular}


Hydrologic Modeling System (HMS), the commercial software used in this study only accepts grid type DEM as input. Then grid DEM is used in this study to generate the watershed boundaries. As will be discussed in the Chapter 4, the data size of the grid DEM is pretty big and it will take a long time to finish the watershed boundary calculations.

\subsubsection{Algorithms for Watershed Delineation}

Three main methods were examined by Skidmore (1990) for calculating ridge and gully position in the terrain. They are summarized as follows:

(1) Peucker and Douglas algorithm

Peucker and Douglas (1975) mapped ridges and valleys using a simple moving-window algorithm. The cell with the lowest elevation in a $2 \times 2$ moving window is flagged. After the algorithm has passed over the DEM, the unflagged cells remained present ridges. Similarly the cell with the highest elevation in the window is flagged, and unflagged cells in the DEM correspond to valley lines.

(2) O'Callaghan and Mark algorithm

O'Callaghan and Mark (1984) described an algorithm for extracting stream and ridge networks from a DEM. This algorithm quantifies the drainage accumulation at each cell in the DEM. Cells which have a drainage accumulation above a user-specific threshold 
are considered to be on a drainage channel. Ridges are defined as cells with no drainage accumulation.

\section{(3) Band algorithm}

Band (1986) proposed a method for identifying streamlines from a DEM, which enhances the Peucker and Douglas algorithm by joining 'broken' stream lines. Ridges and streamlines were thinned to one cell wide using the Rosenfeld and Kak (1982) thinning algorithm. The upstream and downstream nodes on each stream fragment are then flagged. Each downstream node is "drained" along the line of maximum descent until it is connected with another streamline. The streams are again thinned to the final, one-cell wide, line representation of the stream work.

Recently, many researches have been done to improve these algorithms, and many GIS modules are availabe for processing DEMs and delineating watersheds. Skidmore (1990) compared these three methods for mapping streams and ridges from the DEM with a new algorithm that utilizes basic map delineation. The new algorithm generated a satisfactory image of streams and ridges.

The Peucker and Douglas algorithm and O'Callaghan and Mark algorithm produced images with broken streams in flat areas. The delineation produced by the Band algorithm caused a larger number of streams to appear in the flatter parts of the study area.

The HEC-HMS used in this project to generate the watershed employes a procedure differs somewhat from the O'Callaghan and Mark algorithm, but is similar to the one recommended by Mark (1988). 
In the following two sections, the limitations of the DEM in watershed delineation are discussed.

\subsubsection{Effect of DEM Resolution on the Watershed Delineation}

Generally, the resolution of a given DEM plays a critical role in hydrologic simulation.

Numerous studies have examined the sensitivity of terrain attributes to DEM data source and grid resolution, and several works have explored what resolution is needed to accurately represent the key hydrological and geomorphical processes operating in selected landscapes (Quinn et al.,1991; Wolock and Prices 1994; Quinn et al., 1995; Moore,1996). Choosing a coarse resolution DEM to derive the slope, and using this in a surface runoff model has two principal effects. One is to shorten the drainage length, because many of the nature meanders or crookedness of the drainage network is shortcircuited by connecting grid cells together by way of the principal slope. The other effect is a flattening of the slope due to a sampling of hills and valleys at a coarse resolution (Wilson et al, 2000; Vieux, 2001). Zhang and Montgomery (1994) recommended using DEMs with $10 \mathrm{~m}$ resolution for geomorphical and hydrological applications because such DEM performed much better than the ones with $30 \mathrm{~m}$ and $90 \mathrm{~m}$ resolutions and only slightly worse than the DEMs with $2 \mathrm{~m}$ and $4 \mathrm{~m}$ resolution. Grid sizes of $50 \mathrm{~m}$ or more tend to ignore the existence of the lower order streams and they artificially smooth landforms in complex landscapes so that the terrain features that modulate key hydrological processes are lost (Dikau, 1989; Quinn et al., 1991; Quinn et al., 1995). 
The current high resolution satellite imaging capabilities allow us to get 2m DEM's from stereo IKONOS Satellite data or $15 \mathrm{~m}$ DEM's from widely available Stereo ASTER satellite sensors. The DEM data used in this study were generated by interpolating contour map by Ontario Ministry of Natural Resources, with a resolution of $10 \mathrm{~m}$.

\subsubsection{Problems with Flat Areas}

Purely flat landscapes, or zero slope, seldom occur in nature. When a landscape is represented by a DEM, the areas of low relief can be viewed as flat surfaces. This flatness may also be a result of the quantization of the elevation data. Flat surfaces typically are the result of inadequate vertical DEM resolution, which can be further worsened by a lack of horizontal resolution. Such surfaces are also generated when depressions in the digital landscape are removed by raising the elevations within the depressions to the level of their lowest flow (Vieux, 2001).

A variety of methods have been proposed to address the problem of drainage analysis over flat surfaces. Those methods range from simple DEM smoothing to arbitrary flow direction assignment. However, they have limitations. DEM smoothing introduces the loss of information to the already approximate digital elevations, while arbitrary flow direction assignment can produce patterns that reflect the underlying assignment scheme, which are not necessarily realistic or topographically consistent (Vieux, 2001).

Garbrecht and Martz (1997) presented a new approach to address this problem. The new numerical algorithm modifies flat surfaces to produce more realistic and topographically consistent drainage patterns than those provided by earlier methods. The algorithm 
increases cell elevation of the flat surface to include information on the terrain configuration surrounding the flat surface. As a result, two independent gradients are imposed on the flat surfaces: one is away from the higher terrain into the flat surface, and the other is out of the flat surface towards lower terrain. The linear combination of both gradients, with localized corrections, is sufficient to identify the drainage pattern while at the same time satisfying all boundary conditions of the flat surface.

One of the most satisfactory methods for assigning drainage directions on flat areas was developed by Jenson and Donminique (1988). The algorithm is useful over most of the DEM but does not produce satisfactory results in areas of drainage lines because it causes these lines to be parallel. The algorithm assigns drainage directions to flat areas in valleys and drainage lines so that flow is concentrated into single lines, and it uses this method over the rest of the DEM where less convergent flow becomes more realistic.

Now automatically produced drainage network is likely to be very accurate in flat areas, because drainage directions across these areas are not assigned using information directly held in the DEM (Vieux, 2001).

\subsection{Integration of GIS with Hydrological Modelling}

Original attempts to link GIS to hydrologic modelling began in the mid 1970s (Correia et al., 1998). Not until the early 1990s when GIS increased its functionality did hydrology really take advantage of this new technology. GIS expanded the possibilities of hydrological modelling since it can handle a large amount of data. The main function of 
GIS in hydrology is to assist in the management of land and water resources (Meijerink et al., 1994). For example, the parameters of the hydrological models are related to soil characteristics and land use. Soil characteristics can be derived from the existing hydrogeological and soil maps. Land use maps can be generated by aerial photography.

\subsubsection{GIS and Hydrological Model Coupling Method}

Most current hydrological models that take advantage of GIS link to other programs to perform the hydrological analysis. The coupling of hydrological and hydraulic models with GIS is a very fruitful way of studying different scenarios. This coupling still raises difficulties because relations seem weak in GIS compared with hydrological models. GIS is not capable of handling the complex physical laws that control hydrological processes. However, this limitation can be circumvented by doing part of the hydrological and hydraulic calculations in a different system that is linked to GIS.

The way that hydrological analysis is done using GIS is often referred to as either loosely or tightly coupled with any variation in between. Four different approaches have been developed to integrate the GIS: GIS embedded within a hydrological model, a hydrological model embedded within GIS, loose coupling and tight couplings between a hydrological model and GIS (Manson, 2003). Those four approaches have their own advantages and disadvantages.

GIS embedded with a hydrological model has the advantage of giving developers more freedom to design their own system in which the coupling strategy and the use of the 
hydrological component is not dependent or limited by the GIS data structure. The limitation, however, is that the visualization and data management capabilities are not enough comparing with the stand-alone GIS. Furthermore, programming efforts required to achieve this coupling strategy are seen as intensive and occasionally redundant. Some examples of this approach include a variety of the HEC (Hydrological Engineering Centre) series of models developed by the US Army Corps of Engineers, the LDMS (Low-Dimensional Modeling System) as well as the MODFLOW ( 3D finite-difference ground-water Flow Model) (Sui and Maggio, 1999).

The approach in which hydrological models are embedded with a GIS takes advantage of the suite of collection, storage, analysis and visualization capabilities of commercial stand alone GIS packages. In this approach, the hydrological functionality is often criticized and does not often conform to the conventional hydrological modelling. This is especially true in the case of issues relating to model calibration and validation where often models of this type must be calibrated outside by the existing model (Sui and Maggio, 1999). One example of this includes the Environmental Systems Research Institute's (ESRI's) ArcHydro.

In the loose coupling approach, GIS is primarily used to organize data. Loose coupling is commonly done by performing initial analysis in GIS, converting this information into a useable form for hydrological modelling, performing the hydrological analysis, and finally transferring the information back to GIS for display (Hellwegger and Maidment, 1999). Comparing with the tightly coupled analysis, loosely coupled analysis is more 
common because the former needs complex interface. In the tight coupling approach, data analysis is integrated in one program, either the hydrological model or GIS, which has a link to the other program to perform limited operations (VerWest, 2002).

Attempts to couple GIS with hydrological and hydraulic models started in 1975, when the HEC worked on the integration of HEC-1 in GIS using a grid based method. The result of this effort was HEC-SAM (Spatial Analysis Methodology). In this approach, GIS served simply as a database to feed the hydrological model (Males and Grayman, 1992). Windows program HEC-GeoHMS has been developed, which is used in this project.

Because the loose coupling approach is the most popular method for the above mentioned reasons, there exist numerous examples based on it. For example, the GRASS GIS package was linked with TOPMODEL to examine the effects of soil heterogeneity in a small watershed. TOPMODEL is a topographically based surface water model developed in 1979 (Beven and Kirkby, 1979). This semi-distributed model makes directly use of detailed DTM data.

Some popular GIS based hydrological models can be found in Singh (1995) and Shamsi (2002).

\subsubsection{Limitations of GIS in Hydrological Modelling}

Several differences between GIS and hydrological models limit the effectiveness of the coupling between them (Frey, 2004). 
- GIS is made for processing a vast amount of data, while hydrological models are rather concerned by very precise and detailed analysis of a small area. This difference makes that GIS is insufficient to process hydrological data.

- Hydrological models are time varying, particularly for surface water flow, and GIS has no explicit representation of time in its data structure. This is why GIS is mainly used for data input and output.

- GIS and hydrological models do not use the same idea on relationship among data. In GIS, a relation is a simple association between two sets of data using a key item common to them. In hydrological models, a relation is usually expressed as a complex mathematical function.

Romanowicz et al. (1993) pointed that the limitations of this coupling attempt from a hydrological point of view. DeVautier and Feldman (1993) presented a complete review of GIS-based hydrological modelling approaches. Correia et al. (1997) also addressed this topic.

The major weakness of GIS is that the time based processes are not easily accommodated. To circumvent this limitation, it is possible to couple the GIS with a peripheral computer in which the hydrological and hydraulic models are run. Results from these models can be transferred back to the GIS and then the space based operations can proceed in this system. This approach has been proved to be a suitable approach for the hydrological models being used (XSRAIN and OMEGA) and the hydraulic model used for flood mapping (HEC 2) (Correia et al., 1998). There is also a trend among commercial GIS towards a better interface with a wider range of data types and a closer integration within 
a single software system of what were once separated and disparate software capabilities, such as hydrological modelling in ArcView.

\subsection{Calculation of Runoff in Urban Areas}

Accurate estimation of runoff from either rainfall or irrigation is critical for water resource management. In the recent years, the use of remote sensing and GIS technologies in runoff estimation from watersheds has gained increasing attention (Tan et

al., 2002). The SCS (Soil Conservation Service) curve number method is a simple, widely used and efficient method for determining the approximate amount of runoff from a rainfall event in a particular area. Although the method is designed for a single storm event, it can be scaled to find average annual runoff values (Purdue Research Foundation, 2004).

\subsubsection{Characteristics of Runoff in Urban Areas}

Urban areas can pose significant threat to the health of local water bodies and can jeopardize the beneficial use of these water bodies. These areas usually include metropolitan regions that consist of a heavily developed urban core surrounded by a residential, suburban zone. The urban core, or the city, is characterized by a dense concentration of commercial and industrial land uses interwoven by a complex system of streets, parkways, and highways. Developed urban areas play a crucial role in the hydrological regime since they create large impervious surface areas. 
Generally, the effects of urbanization on runoff from a basin include higher volume, higher peak discharge, and shorter time of concentration. These changes are associated with the increased imperviousness and more efficient drainage that are characteristic of constructed drainage systems.

\subsubsection{SCS Curve Number Method}

In 1972, the U. S. Soil Conservation Service suggested an empirical model for rainfall abstractions, namely the SCS curve number method, which is based on the potential for soil to absorb a certain amount of moisture. On the basis of field observations, the potential storage $S$ (in millimetres or inches) is related to the curve number $(C N)$ which is a characteristic of soil type, land use and initial degree of saturation known as the antecedent moisture condition. During the sub-basin runoff simulation, the selected basins are assumed to be independent from one to another. The simulation of a storm event over a watershed is then realized one basin at a time (Vieux, 2001).

There are many hydrological/water quality models such as CREAMS (Knisel, 1980), GLEAMS (Leonard et al., 1986), and AGNPS (Young et al., 1985). All of the these models use the SCS curve number method to estimate the surface runoff volume. Some famous hydrological modelling softwares, such as L-THIA (Purdue Research Foundation, 2004), and HEC-HMS by Hydrological Engineering Center, use the SCS curve number method to estimate the runoff within a watershed. Even in the waste management, the SCS method is used to calculate the volume of leachate (Oweis, 1998). 
The SCS technique is now commonly used because (a) it is reliable and has being used for many years in the United States; (b) it is computationally efficient; (c) its inputs are generally available ; and (d) it relates runoff to soil type, land use and management practices (Shamsi, 2002).

The main advantage of the SCS curve number method is its simplicity. In the SCS method, the decisive factors of the runoff volume are land cover and soil type. For a given area, the change of its soil takes usually a very long time under the nature background, especially in urban areas. However land cover types can change in a few months. So the SCS method is a good method to evaluate the effect of urbanization on the runoff. This method has been used to assess the hydrological impacts of land use change by some researchers (Chou et al., 1988; McClintock et al., 1995; Bhaduri et al., 1997; Forney et al., 2001; Weng, 2001). In this study, the SCS method is employed to quantify increases in the runoff associated with urbanization in the Toronto Region.

Technical Release 55 (TR-55), "Urban Hydrology for Small Watersheds", presents simplified procedures to calculate the storm runoff volume based on the SCS method under the urbanizing setting. This study will follow the instruction in TR-55 to calculate the runoff in the selected area. More details of the methodology are presented in Chapter 3. 


\section{Chapter 3}

\section{METHODOLOGY}

DEM and GIS have been testified to be efficient tools for urban hydrological modelling. As a useful tool for hydrological analysis, DEM data are widely applied to delineate watershed boundaries and stream networks. GIS provides a flexible environment for entering, analyzing, and displaying digital data from various sources necessary for urban feature identification, change detection, and database development. In this study, GIS will be employed to organize and process elevation data.

\subsection{Study Area}

The Toronto watershed is selected as the study area in this study. Toronto watershed is a tertiary watershed, managed by the Toronto Region (see Figure 3.1). From Figure 3.1 it can be seen that the selected Toronto Region is bigger than the City of Toronto, but within the Greater Toronto Area (GTA).

The Toronto Region was originally listed as an Area of Concern (AOC) because of many complex problems (Environment Canada, 2001). One reason was that the contaminants associated with rapid stormwater runoff and melting from these watersheds create serious impacts on the rivers and streams as well as the waterfront itself. 


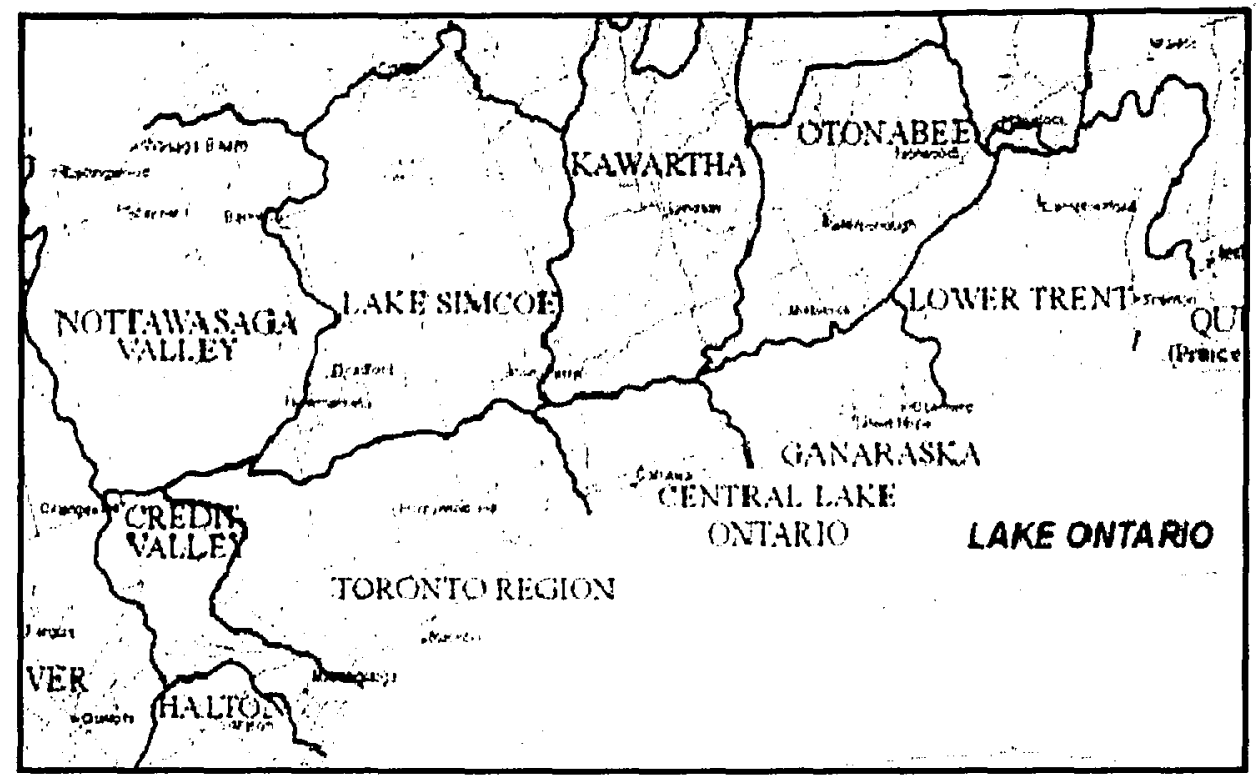

Figure 3.1 Conservation authority of the Toronto Region (Environment Ontario, 2004)

\subsection{Data Sources}

It is important to identify the data to meet project needs. Spatial data come in different formats, such as resolutions, intended uses and the prices etc. Before collecting data, the project specifications should be reviewed. When there are no specifications for one project, the goals of the project can help define acceptable data in terms of data storage, resolution, and accuracy.

Based on the objectives and methodology of this project, the main data required are DEMs, soil and land cover data. 


\subsubsection{DEM Data}

As mentioned in Chapter 2, DEMs with $10 \mathrm{~m}$ resolution are recommended for hydrological application. In this study, the DEM data with this resolution were used, which were available in the Ryerson Library. The DEMs were created through the Water Resources Information Project (WRIP), Ontario Ministry of Natural Resources, Peterborough. They were interpolated using ANUDEM 4.6.3 software with NRVIS (Natural Resources \& Values Information System) contour and water virtual flow as inputs, which were collected and updated over the specified time period from 1976 to 2002. The DEMs were created during the time period from January 8, 2001 to December 20, 2002. Table 3.1 lists the mapping information of the DEM data.

Table 3.1 Mapping Information of DEM data

\begin{tabular}{|c|c|c|}
\hline \multicolumn{2}{|l|}{ Grid Coordinate System Used } & Universal Transverse Mercator \\
\hline \multicolumn{2}{|l|}{ Map Projection } & Transverse Mercator \\
\hline \multicolumn{2}{|l|}{ Horizontal Geodetic Datum } & North American Datum of 1983 \\
\hline \multicolumn{2}{|l|}{ Vertical Geodetic Datum } & $\begin{array}{l}\text { Canadian Geodetic (height) Datum of } \\
1928 \text { - Canadian }\end{array}$ \\
\hline \multirow[t]{2}{*}{ Position Accuracy of Features } & Horizontal & $+/-10 \mathrm{~m}$ \\
\hline & Vertical & $+/-5 \mathrm{~m}$ \\
\hline
\end{tabular}

\subsubsection{Soil Data}

The soil data were obtained from the National Soil DataBase (NSDB). The data were transferred from copies of paper maps based on field observations in 1950 s by Agriculture and Agri-food Canada (AAFC). Although reliability studies have not been conducted, soils were sampled on representative landscapes and model profiles were chosen for field description, sampling and analyses by the producer. The data are in the Arc/Info format, published in 2000 . The projection is geographic, with the datum North 
American Datum of 1927. Each soil file covers one county. In this study, four counties, Simcoe, York, Dufferin, and Peel were included (see Figure 3.2). In Figure 3.2, the number 31 represents Simcoe; 32 represents York; 35 and 36 represent Dufferin and Peel respectively.

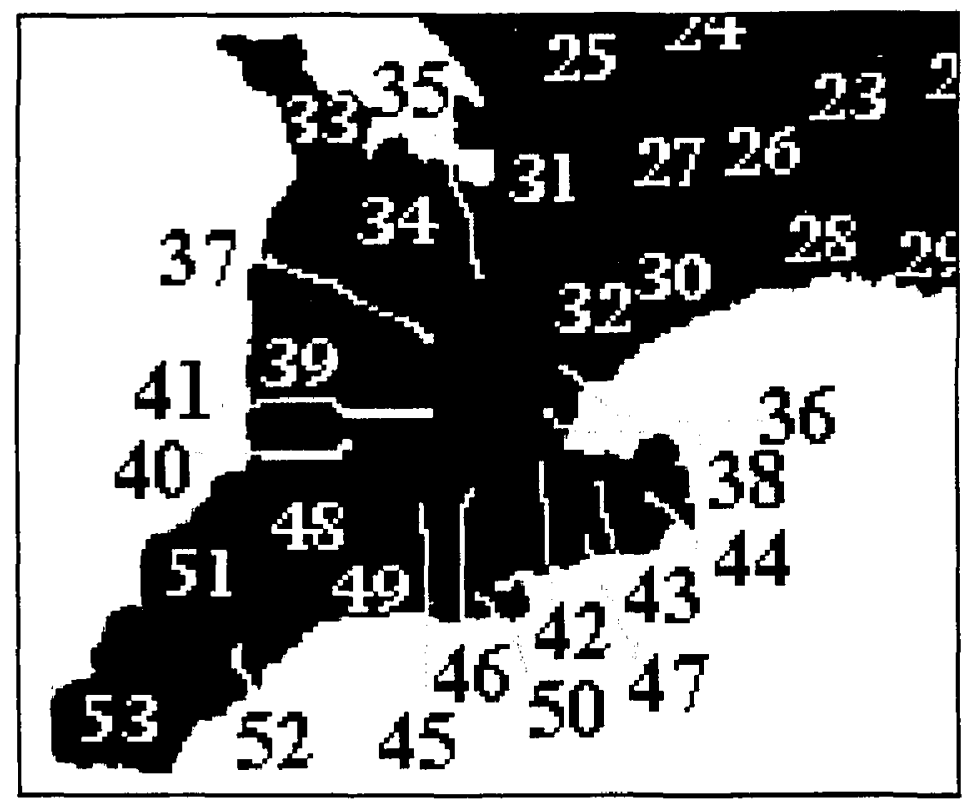

Figure 3.2 Counties in Ontario (Ontario Genweb, 2004)

\subsubsection{Land Use Data}

To compare the effect of land use changes upon the runoff, two sets of land cover data were used.

CanMap RouteLogistics 7.2 (Ontario). The data cover the whole Ontario. The land use data were created by DMTI Spatial Inc. (2003). Then the data set was used to represent the land cover in 2003. The file is displayed as unprojected Longitude-Latitude and in NAD83 datum. The land cover in 2003 covering GTA is shown in Figure 3.3. 
National-Scale Ontario Land Cover. The Ontario Land Cover database was produced by the Ontario Ministry of Natural Resources from satellite image data. The land cover mapping classification was derived from digital, multispectral Landsat Thematic Mapper (TM) image data recorded on a range of dates between 1986 and 1997, the majority in the early 1990s. This data set is regarded as the land cover situation in the early 1990s. Three tiles covering the study area were obtained from GeoGratis (2004).

The Ontario land cover classification reflects the nature of the land surface rather than land use. For example, provincial parks were mapped as areas of recreational land use, but they are mosaic of water bodies, forest, wetlands, and other cover classes. The details of the land cover in the early 1990s are shown in Figure 3.4.

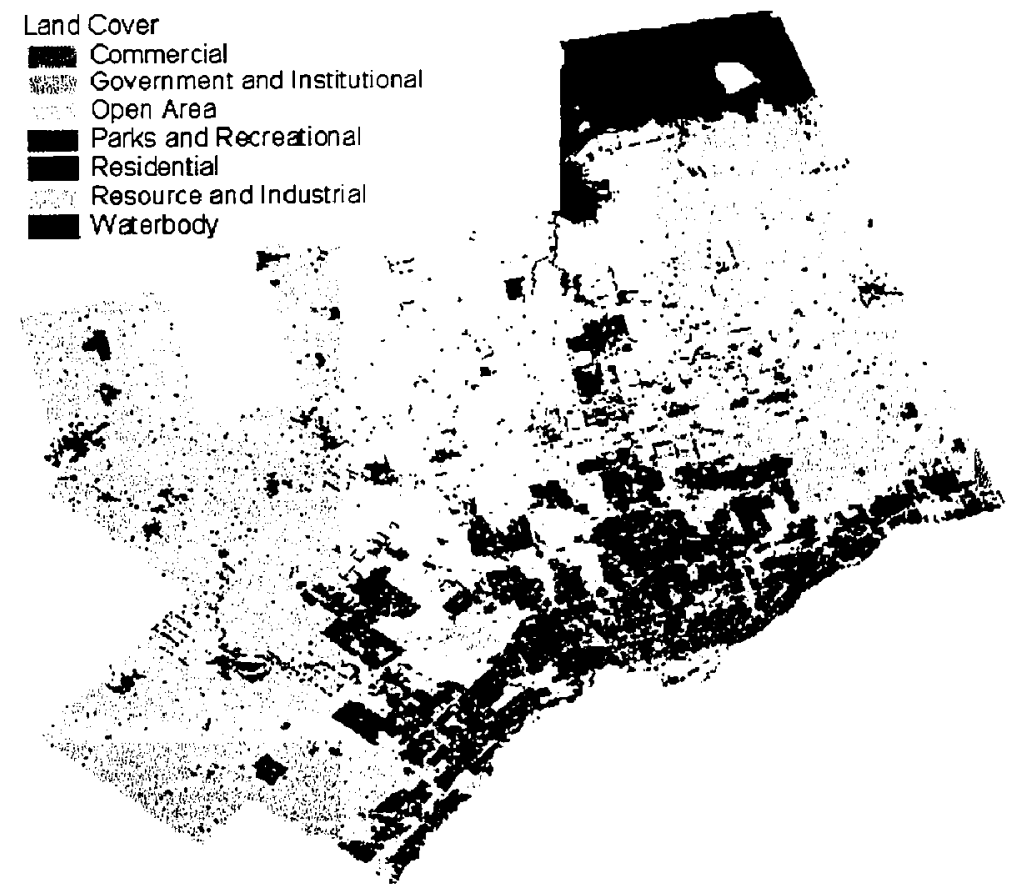

Figure 3.3 Land cover of the Toronto Region in 2003 


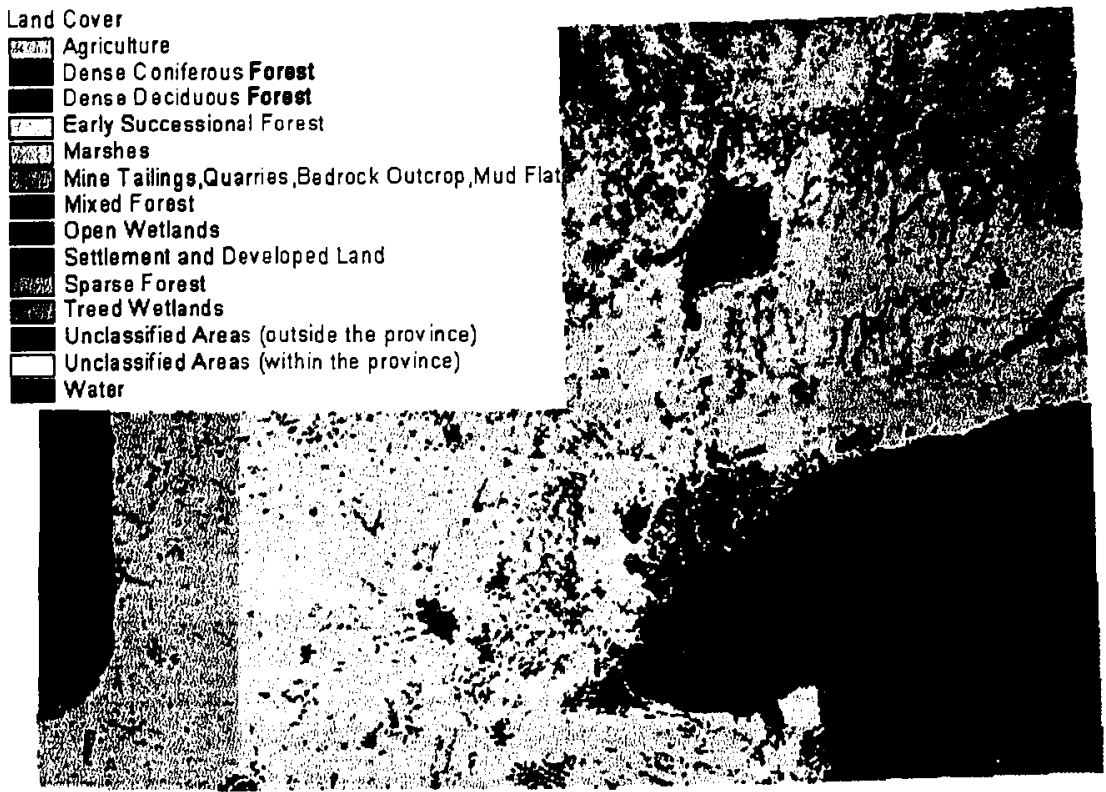

Figure 3.4 Land cover of the Toronto Region in the early 1990s

GIS software and tools used in this study include ArcView and its extension HEC-HMS, XTools, as well as ERDAS Imagine.

\subsection{Watershed Generation}

The functions for hydrological analysis available in different software packages are very similar. The Geospatial Hydrologic Modelling (HEC-GeoHMS) extension of Arcview GIS is a relatively popular software package. It was developed by HEC. GeoHMS uses ArcView and its Spatial Analyst extension to input a number of data for hydrological modelling. The HEC-GeoHMS analyzes the digital terrain information and transforms the drainage paths and watershed boundaries into a hydrological data structure that represents the watershed response to precipitation. The HEC-GeoHMS can also transform the drainage paths and watershed responding to precipitation. In addition to the hydrological data structure, it can develop grid-based data for linear quasi-distributed 
runoff, transformation, HEC-HMS basin model, physical watershed, stream characteristics, and background map file (The Hydrologic Engineering Center, 2003).

The main function of HEC-GeoHMS, terrain processing, is to modify, process and analyze the terrain. After the terrain processing, the physical characteristics of the streams and subbasins can be extracted, such as the length and slope of the stream, the longest flow lengths, etc. In this process, a terrain model is used as an input to derive eight additional data sets that collectively describe the drainage patterns of the watershed and can delineate stream and subbasin. The steps in terrain processing and their purposes are shown in Table 3.2.

Table 3.2 Function of each step in terrain processing

\begin{tabular}{|l|l|}
\hline \multicolumn{1}{|c|}{ Step } & \multicolumn{1}{c|}{ Function } \\
\hline Fill Sinks & Filling the depression or the pit to determine flow directions \\
\hline Flow Directions & Defining the steepest descent for each terrain cell \\
\hline Flow Accumulation & $\begin{array}{l}\text { Determining the number of upstream cells draining to each } \\
\text { cell }\end{array}$ \\
\hline Stream Definition & $\begin{array}{l}\text { Classifying all cell which greater than certain threshold as } \\
\text { stream network }\end{array}$ \\
\hline Stream Segmentation & Dividing the stream into segments \\
\hline Watershed Delineation & Delineating a watershed for every stream segment \\
\hline Watershed Polygon & Converting subbasins from grid representation to vector \\
\hline $\begin{array}{l}\text { Stream segment } \\
\text { processing }\end{array}$ & Converting stream segment from grid presentation to vector \\
\hline Watershed Aggregation & $\begin{array}{l}\text { Aggregating the upstream subbasins at every stream } \\
\text { confluence }\end{array}$ \\
\hline
\end{tabular}

The depressionless DEM is created by filling the depressions or pits by increasing the elevation of the pit cells to the level of the surrounding terrain in order to determine flow directions. 
The pits are often considered as errors in the DEM due to re-sampling and interpolating the grid. For example, in a group of $3 \times 3$ cells, if the center cell has the lowest elevation compared with its eight neighboring cells, then the center cell's elevation will be increased equaling the next lowest cell. Filling the depressions allows water to flow across the landscape. This assumption is generally valid when a large event storm fills up the small depressions and any incremental amount of water that flows into the depression will displace the same amount of water from the depression (The Hydrologic Engineering Center, 2003).

Flow direction matrix is formed by selecting the cell with the maximum downward slope of the eight directions. Similar to a compass, the eight-point pour algorithm specifies the eight possible directions (see Figure 3.5).

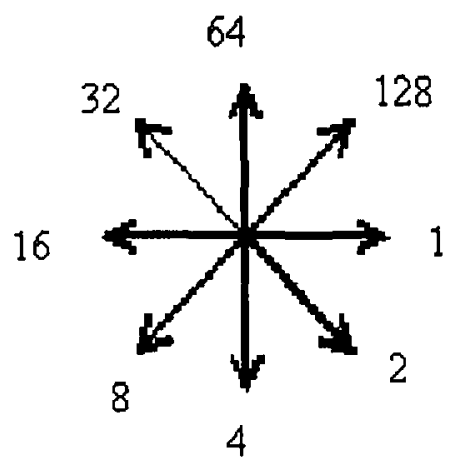

Figure 3.5 The flow directions defined in the HEC-HMS

Flow accumulation calculates the number of upstream cells draining to a given cell is determined Stream Definition step. Upstream drainage area at a given cell can be calculated by multiplying the flow accumulation value by the cell area. 
Cells with the flow accumulation that is greater than the threshold defined by users are classified as stream. Typically, cells with high flow accumulation are considered as part of a stream network. The user-specified threshold may be specified as an area in distance units squared, e.g., square miles, or as the number of cells. The flow accumulation for a particular cell must exceed the user defined threshold for a stream to be initiated. The default is one percent of the largest drainage area in the entire basin. The smaller the chosen threshold is, the greater the number of subbasins delineated by the Geo-HMS is.

\subsection{Runoff Calculation using SCS Method}

Runoff calculation is referred to Technical Release 55 (TR-55). TR-55 presents simplified procedures to calculate storm runoff volume, peak rate of discharge, hydrographs, and storage volumes required for floodwater reservoirs. These procedures are applicable in small watersheds, especially urbanizing watersheds, which match the research objective very well. The basic calculations in TR-55 are coming from the SCS curve number method. The model described in TR-55 begins with a rainfall amount uniformly imposed on the watershed over a specified time distribution.

Let $P$ be the total rainfall and $I_{a}$ an initial abstraction, and the effective rainfall $P_{c}=P-I_{a}$. After allowing for the initial abstraction, the amount of infiltration and surface retention is $F$, and the potential or maximum retention is $S$. Storm runoff, $Q$, can be related to the effective rainfall and actual retention through water balance.

$$
Q=P_{c} * F
$$


The critical assumption of the SCS method is that the ratio of runoff to effective rainfall is the same as the ratio of actual retention to potential retention, i.e.

$$
\frac{Q}{P_{c}}=\frac{F}{S}
$$

Combine Equation (3.1) and (3.2) yields the SCS runoff equation

$$
Q=\frac{P_{c}^{2}}{P_{c}+S}
$$

To obtain volumes, $P$ and $Q$ (in inches) must be multiplied by the basin area.

The Equation (3.3) for the storm runoff is at the core of the SCS method.

The initial abstraction $I_{a}$ was found to be approximately $0.2 S$ (SCS, 1969, 1972, 1985), and the potential retention $S$ becomes the only parameter for the runoff calculation.

$$
Q=\frac{(P-0.2 S)^{2}}{(P+0.8 S)}
$$

The potential retention $S$ is commonly expressed in terms of a runoff curve number (CN) through the relationship

$$
S=1000 / C N-10
$$

where $S, 1,000$ and 10 are given in inches (U.S. Department of Agriculture, 1972). Then runoff is only related with rainfall and curve number.

To save time, the procedures in TR-55 are simplified by assumptions about some parameters. These simplifications, however, limit the use of the procedures and can provide results that are less accurate than ones obtained from more detailed methods. 


\subsection{Curve Number}

The $\mathrm{CN}$ provides a simple and robust means of estimating excess rainfall (King et al., 2004), which is a dimensionless watershed parameter ranging from 0 to 100 . A CN of 100 represents a limiting condition of a perfectly impermeable watershed with zero retention and thus all the rainfall becoming runoff. A CN of zero conceptually represents the other extreme, with the watershed abstracting all rainfall with no runoff regardless of the rainfall amount (Gumbo et al., 2001). Curve numbers have been calibrated, evaluated, and assigned for many sets of measured runoff data and are known to be generally reliable over a wide range of geographic, soil, and land management conditions.

$\mathrm{CN}$ is based on soils, plant cover, amount of impervious areas, interception, and surface storage.

\subsubsection{Hydrological Soil Groups}

Infiltration rates of soils vary widely and are affected by subsurface permeability as well as surface intake rates. Soils are classified into four Hydrologic Soil Groups (HSGs) (A, $\mathrm{B}, \mathrm{C}$, and D) according to their minimum infiltration rate, which is obtained for bare soil after prolonged wetting.

The four groups are defined by the SCS as follows.

Group A soils have low runoff potential and high infiltration rates even when thoroughly wetted. They consist chiefly of deep, well to excessively drained sand or gravel and have a high rate of water transmission (greater than $0.30 \mathrm{in} / \mathrm{hr}$ ). 
Group B soils have moderate infiltration rates when thoroughly wetted and consist chiefly of moderately deep to deep, moderately well to well drained soils with moderately fine to moderately coarse textures. These soils have a moderate rate of water transmission $(0.15-0.30 \mathrm{in} / \mathrm{hr})$.

Group C soils have low infiltration rates when thoroughly wetted and consist chiefly of soils with a layer that impedes downward movement of water and soils with moderately fine to fine texture. These soils have a low rate of water transmission $(0.05-0.15 \mathrm{in} / \mathrm{hr})$.

Group D soils have high runoff potential. They have very low infiltration rates when thoroughly wetted and consist chiefly of clay soils with a high swelling potential, soils with a permanent high water table, soils with a claypan or clay layer at or near the surface, and shallow soils over nearly impervious material. These soils have a very low rate of water transmission $(0-0.05 \mathrm{in} / \mathrm{hr})$.

As a result of urbanization, the soil profile may be considerably altered and the listed group classification may no longer apply. In these circumstances, the following method can be used to determine HSG according to the texture of the new surface soil, provided that significant compaction has not occurred (Brakensiek and Rawls, 1983). Table 3.3 lists the soil textures responding to each HSG soil group.

Table 3.3 HSG soil textures

\begin{tabular}{|c|l|}
\hline HSG soil group & \multicolumn{1}{|c|}{ Soil textures } \\
\hline A & Sand, loamy sand, or sandy loam \\
\hline B & Silt loam or loam \\
\hline C & Sandy clay loam \\
\hline D & Clay loam, silty clay loam, sandy clay, silty clay, or clay \\
\hline
\end{tabular}




\subsubsection{Land Cover}

Table 3.4 addresses most land cover types, such as vegetation, bare soil, and impervious surfaces. The curve number is decided by land covers and hydrologic soil groups together.

Table 3.4 Curve number definitions in the TR-55

\begin{tabular}{|l|l|l|l|l|l|l|}
\hline \multirow{2}{*}{$\begin{array}{l}\text { Land Use } \\
\text { Description } \\
\text { on Input } \\
\text { Screen }\end{array}$} & \multicolumn{5}{|c|}{ Cover Description } & \multicolumn{3}{|c|}{$\begin{array}{l}\text { Curve Number for } \\
\text { Cover Type and Hydrologic } \\
\text { Condition }\end{array}$} & $\begin{array}{l}\text { HS } \\
\text { Impervious } \\
\text { Areas }\end{array}$ & A & B & C & D \\
\hline Agricultural & $\begin{array}{l}\text { Row Crops - Staight Rows } \\
\text { Crop Residue Cover- Good } \\
\text { Condition }\end{array}$ & 64 & 75 & 82 & 85 \\
\hline Commercial & $\begin{array}{l}\text { Urban Districts: Commerical } \\
\text { and Business }\end{array}$ & 85 & 89 & 92 & 94 & 95 \\
\hline Forest & Woods - Good Condition & & 30 & 55 & 70 & 77 \\
\hline Grass/Pasture & $\begin{array}{l}\text { Pasture, Grassland, or Range - } \\
\text { Good Condition }\end{array}$ & 39 & 61 & 74 & 80 \\
\hline $\begin{array}{l}\text { High Density } \\
\text { Residential }\end{array}$ & $\begin{array}{l}\text { Residential districts by average } \\
\text { lot size: 1/8 acre or less }\end{array}$ & 65 & 77 & 85 & 90 & 92 \\
\hline Industrial & Urban district: Industrial & 72 & 81 & 88 & 91 & 93 \\
\hline Open Spaces & $\begin{array}{l}\text { Open Space (lawns, parks, golf } \\
\text { courses, cemeteries, etc.) Fair } \\
\text { Condition (grass cover 50\% to } \\
70 \%)\end{array}$ & & 49 & 69 & 79 & 84 \\
\hline $\begin{array}{l}\text { Parking and } \\
\text { Paved Spaces }\end{array}$ & $\begin{array}{l}\text { Impervious areas: Paved } \\
\text { parking lots, roofs, drivesways, } \\
\text { etc. (excluding right-of-way) }\end{array}$ & 100 & 98 & 98 & 98 & 98 \\
\hline $\begin{array}{l}\text { Water/ } \\
\text { Wetlands }\end{array}$ & & 0 & 0 & 0 & 0 & 0 \\
\hline
\end{tabular}

The hydraulic condition is based on combination factors that affect infiltration and runoff, including (a) density and canopy of vegetative areas, (b) amount of year-round cover, (c) amount of grass or close-seeded legumes, (d) percent of residue on the land surface (good $>=20 \%$ ), and (e) degree of surface roughness. 
In Table 3.4, the land cover Forest in good condition means that the woods are protected form grazing, and litter and brush adequately cover the soil. The Grass/Pasture is in good condition when more than $75 \%$ ground is covered by grass and lightly or only occasionally grazed.

For a watershed with sub-areas of different soil types and land cover types, a composite curve number $C N_{c}$ is determined by weighting the $\mathrm{CN}$ 's for the different sub-areas in proportion to the total land area associated with each $A_{i}(\mathrm{i}=1,2, \ldots \ldots \mathrm{n})$.

$$
\mathrm{CN}_{\mathrm{c}}=\mathrm{CN}_{1}\left(\mathrm{~A}_{1} / \mathrm{A}_{\text {total }}\right)+\mathrm{CN}_{2}\left(\mathrm{~A}_{2} / \mathrm{A}_{\text {total }}\right)+\ldots+\mathrm{CN}_{\mathrm{n}}\left(\mathrm{A}_{\mathrm{n}} / \mathrm{A}_{\text {total }}\right)
$$

\subsubsection{Limitations of Curve Number}

The major limitation with $\mathrm{CN}$ is the inability to account for rainfall intensity/duration (King et al., 2004).

Curve numbers describe average conditions that are useful for design purposes. If the rainfall event used is a historical storm, the modelling accuracy decreases.

At the same time, the user should understand the assumption reflected in the initial abstraction term $\left(I_{a}\right)$ and should ascertain that the assumption applies to the situation. $I_{a}$, which consists of interception, initial infiltration, surface depression storage, evapotranspiration, and other factors, was generalized as 0.25 based on data from agricultural watersheds ( $S$ is the potential maximum retention after runoff begins). This 
approximation can be especially important in urban applications because the combination of impervious surface areas with pervious surface areas can imply a significant initial loss that may not take place. The opposite effect, a greater initial loss, can occur if the impervious surface areas have surface depressions that store some runoff. Furthermore, runoff from snowmelt or rain on frozen ground cannot be estimated using these procedures.

\subsection{Flow Chart of the Research}

The overall flowchart of the research process is shown in Figure 3.6. First the data have to be integrated into the study area in the format of shp file. Then the DEM data are used to generate watersheds. The area of each watershed is needed in the later calculation. The soil and land cover data should be coded first according to the instruction of TR-55. By intersecting the soil layer with the land cover layers, each polygon will have both the soil and the land cover information. Then the curve number for each polygon can be obtained. The curve number of each watershed is a weighed one. The weight is defined as the ratio of each polygon area to each watershed area. Similarly, the curve number of the whole watershed is the weighted curve number, with the weight defined as the ratio of the each sub-watershed area to the whole watershed area.

In Figure 3.6, the rectangle represents the data or the results, the triangle represents manipulation, and the rounded rectangle represents software used. 


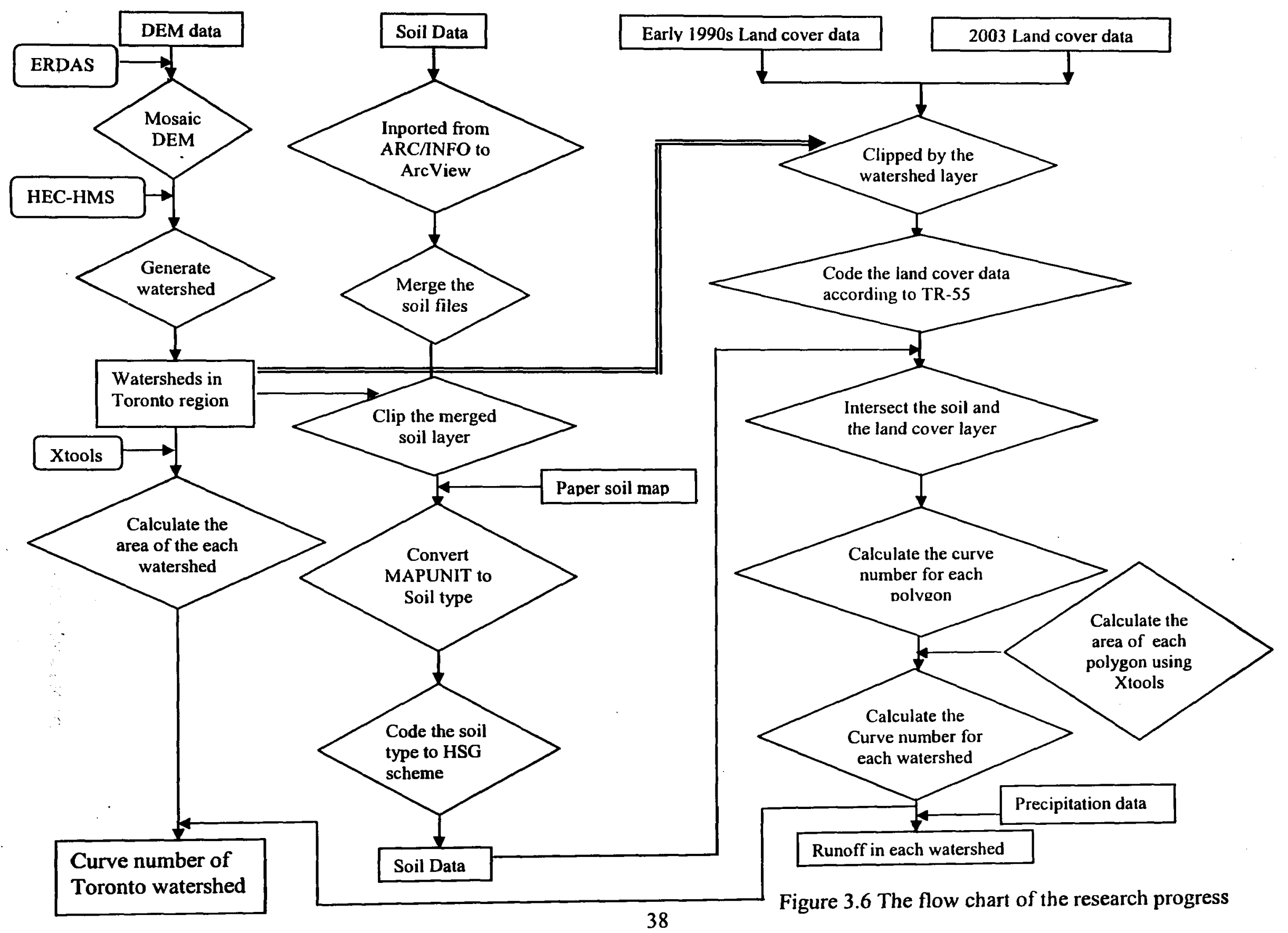




\section{Chapter 4}

\section{RESULTS AND DISCUSSION}

In this chapter, the process of data manipulation and the results were presented, including the watershed boundaries in the Toronto Region, the comparison of curve numbers in the early 1990s and 2003, and the revised curve numbers and runoff of Toronto Region in 2003.

\subsection{Data Processing}

\subsubsection{Mosaic of DEM Data}

There are a total of 142 tiles in the Ontario DEM data set. Five tiles, the $86^{\text {th }}$, the $87^{\text {th }}$, the $90^{\text {th }}$, the $91^{\text {st }}$, and the $92^{\text {nd }}$, cover the Toronto watershed. Figure 4.1 illustrates the location of the tiles used in this research in the DEM tile index. $2 \mathrm{HC}$ in the insert is the Toronto watershed. 


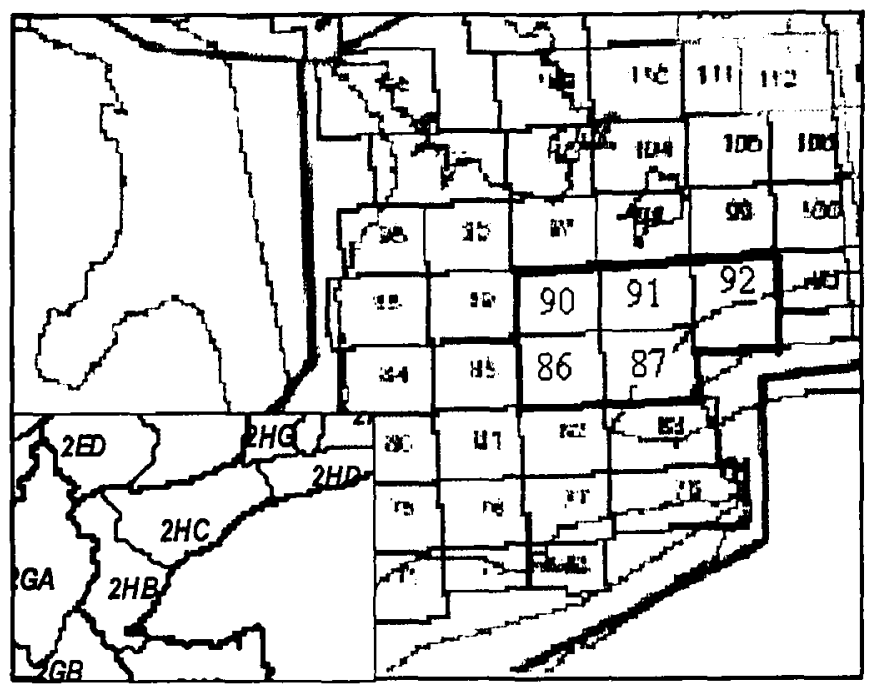

Figure 4.1 DEM tile index in Toronto watershed

There is overlap between each two adjacent tiles to avoid gap. In Figure 4.2 (a), it can be observed that the terrain along the edges between each two tiles does not match. For watershed generation, the DEM data should change continuously. To smooth the data values along the overlap areas, the file tiles are mosaiced using ERDAS Imagine software. The result from mosaicing is shown in Figure 4.2 (b). It shows that the DEM data change continuously.

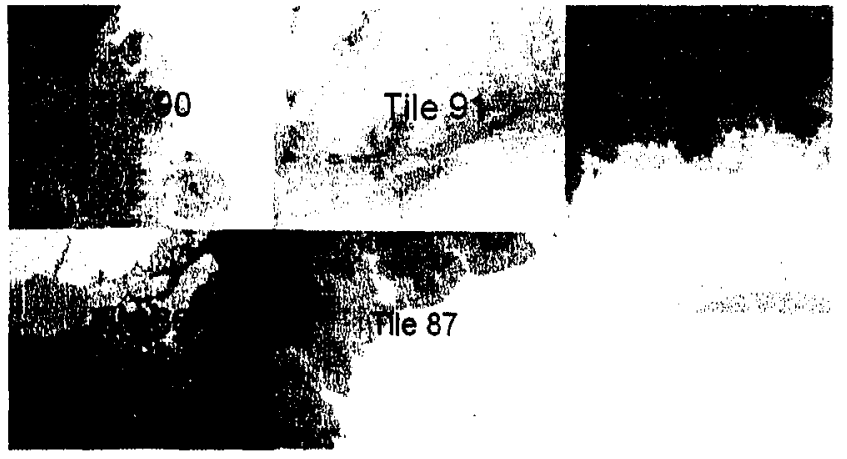

(a)

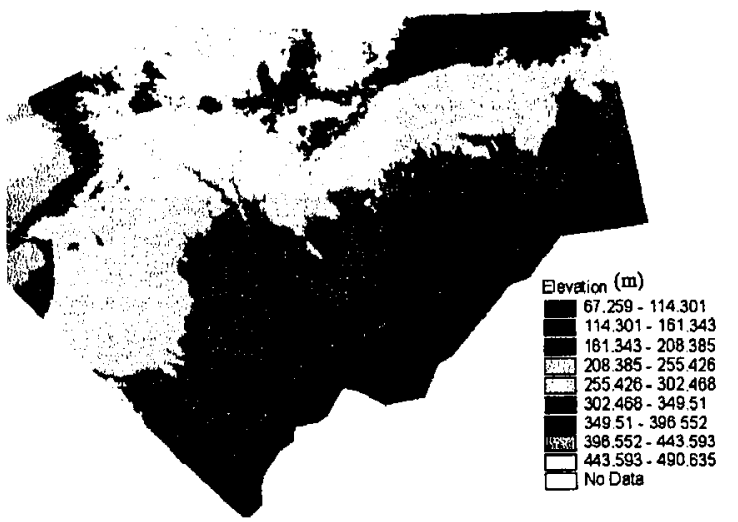

(b)

Figure 4.2 DEM data (a): 5 original tiles; (b): after mosaic 
Figure 4.3 is the 3D visualization of the study area, generated from the TIN. It can be noticed that the elevation decreases gradually from north to south. The south part of the Toronto Region is relatively flat. The valleys are obvious in Figure 4.3. Those valleys are the main streams in the Toronto Region.

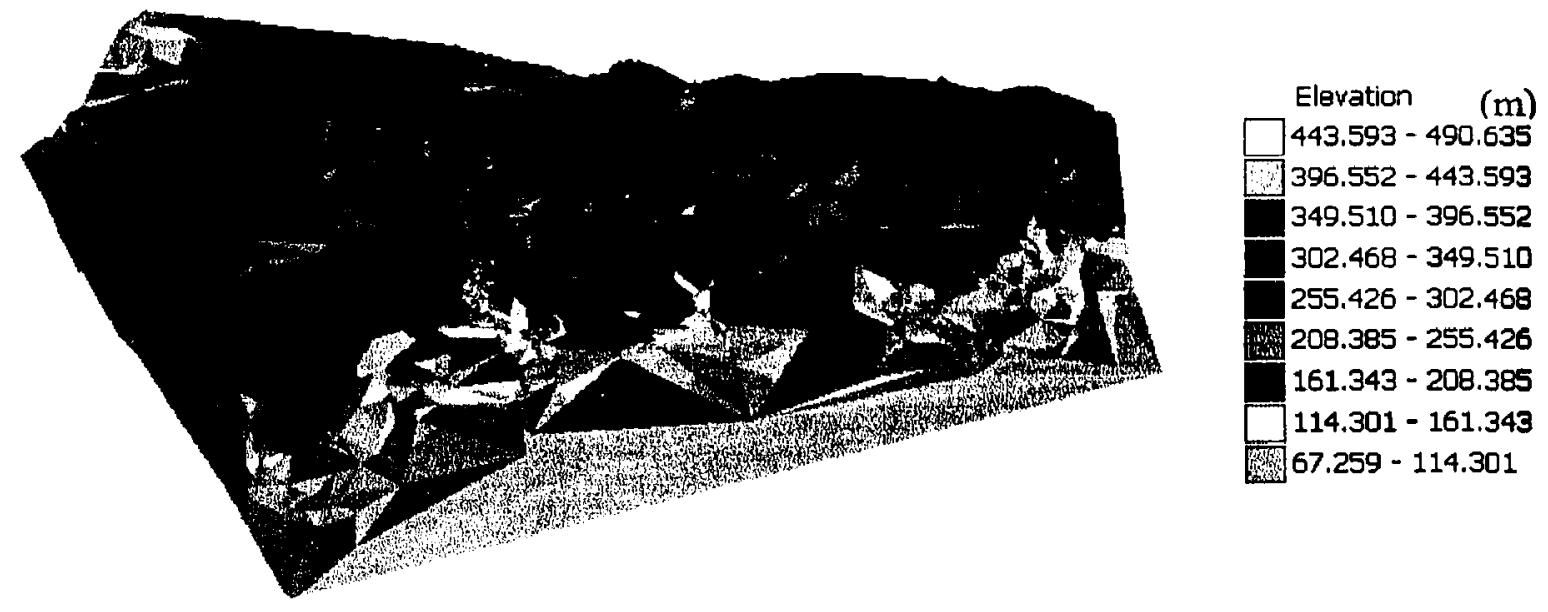

Figure 4.3 3D visualization generated from the TIN

\subsubsection{Watershed Generation}

Since data size is too big, it took several days to finish the first step, Fill sink, of the terrain processing using the HEC-GeoHMS. Then only the DEM containing the study area was clipped (see Figure 4.2 (b)) to generate the watershed. It took almost one week to finish all the calculation of watershed boundaries.

\subsubsection{Coding Soil Data According to HSG Scheme}

The original soil map units are identified by unique symbols on the Soils of Canada map. The key field in the soil attribute table is 'MAPUNIT', generated for each polygon by 
appending the PROVINCE and NSDB-ID codes with the map unit symbol that identified the polygon on the original printed soil map (see Figure 4.4 (a)). In any survey, a group of polygons with similar properties may be coded with the same MAPUNIT. For example, Peel has 35 types of soil, while York has 57 types.

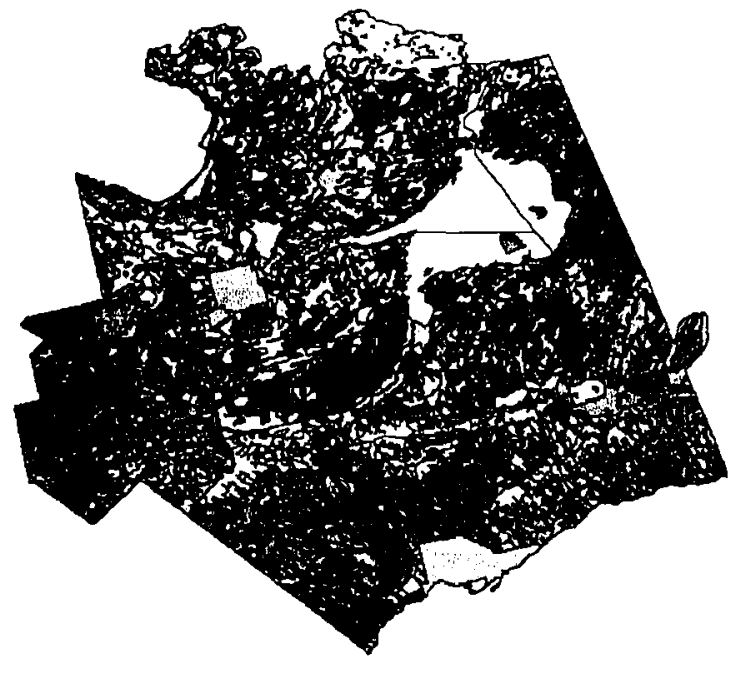

(a)

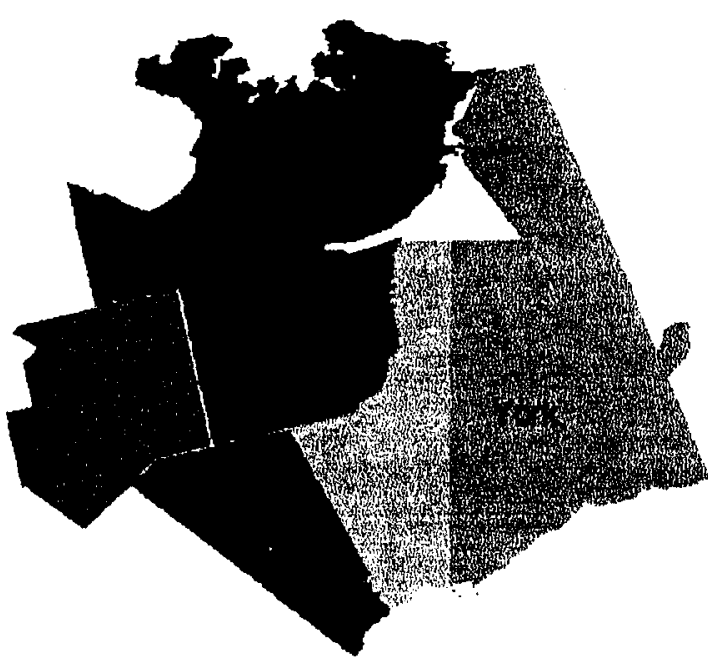

(b)

Figure 4.4 Original soil data

So the original printed soil maps are referred to identify what kind of soil the MAPUNIT represents. Such as for York county, MAPUNIT of ON D012 Gsl represents the sandy loam. According to Table 3.3, sandy loam is A type HSG. Each MAPUNIT was the converted to the HSG soil group (see Figure 4.5), with a total of 328 types of soil being converted. In the Toronto Region, there is no C type HSG. The soil in the downtown area of Toronto was not classified, since most areas are covered by impervious surface (e.g. sidewalks or roads). This area is treated as D type HSG, which has a very poor drainage ability. 
In Figure 4.5, it is obvious that Peel and York counties have high potential of generating runoff, where larger areas are covered by D type of HSG soil.

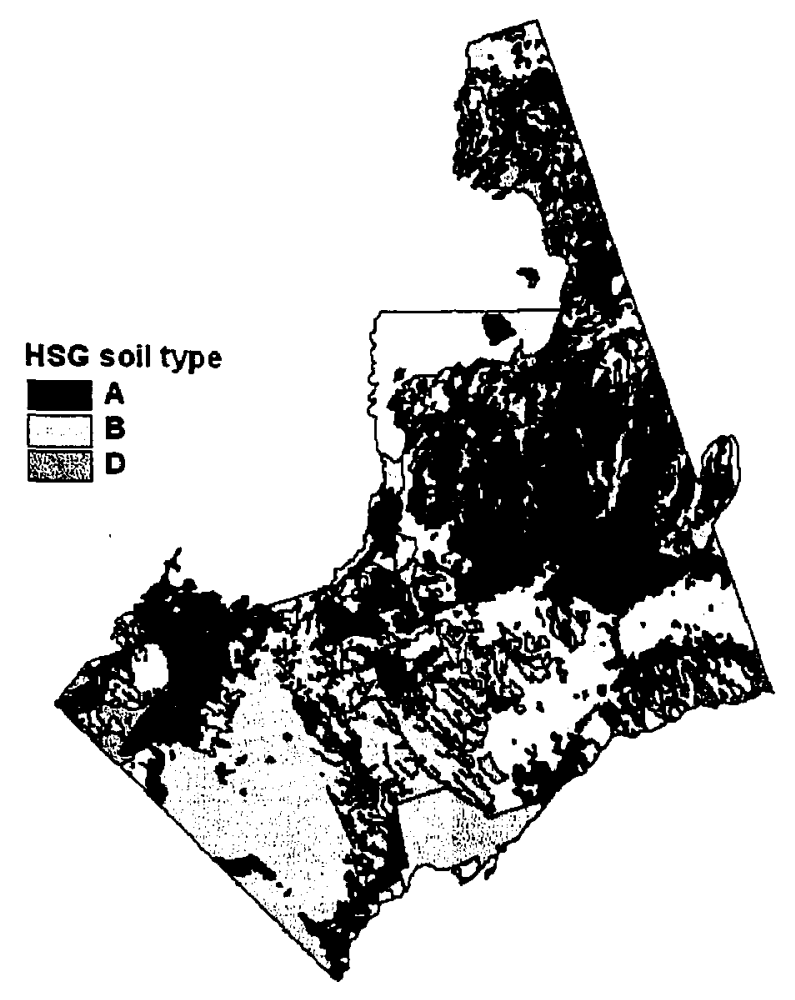

Figure 4.5 Soil (in HSG) distribution

\subsubsection{Coding Land Cover Data According to TR55}

The classification standards of the land cover data employed in this study are different from those in the TR55. For example, in the early 1990s land cover classification scheme, the forest is classified into three kinds, dense coniferous forest, dense deciduous forest and mixed forest. Furthermore, the classification schemes are different between early 1990 s and 2003 land cover data. This may cause error in the further analysis. 
Based on the description of land cover classification coming with the data and of TR55, the land cover data in the early 1990s and 2003 were reclassified according to the standard of TR55 (see Tables 4.1 and 4.2). Some unavoid errors still exist. For example, most agriculture land in 2003 was classified as Open Area. When zooming in the data in the Toronto downtown area, it is found that the roads are viewed as Open Area too. As the area of road is very unsignificant comparing to the area of agriculture land, the Open Area was classified into agriculture. Unclassified Areas (outside the province) is in USA and Unclassified Areas (within the province) is outside of the study area (Toronto Region). So these areas will have no effect on the result.

Table 4.1 Conversion of land cover (early 1990s) according to the TR55 standard

\begin{tabular}{|l|c|}
\hline \multicolumn{1}{|c|}{ Land use (early 1990s) } & TR-55 \\
\hline Agriculture & Agricultural \\
\hline Dense Coniferous Forest & Forest \\
\hline Dense Deciduous Forest & \\
\hline Mixed Forest & \multirow{2}{*}{ Open Spaces } \\
\hline Mine Tailings, Quarries, Bedrock Outcrop, Mud Flats & \\
\hline Early Successional Forest & High Density Residential \\
\hline Sparse Forest & \\
\hline Settlement and Developed Land & Water \\
\hline Marshes & \\
\hline Treed Wetlands & Unclassified \\
\hline Open Wetlands & \\
\hline Water & \\
\hline Unclassified Areas (outside the province) & \\
\hline Unclassified Areas (within the province) &
\end{tabular}

Table 4.2 Conversion of land cover (2003) according to the TR55 standard

\begin{tabular}{|l|l|}
\hline \multicolumn{1}{|c|}{ Land Use (2003) } & \multicolumn{1}{c|}{ TR55 } \\
\hline Commercial & Commercial \\
\hline Open Area & Agriculture \\
\cline { 1 - 2 } Parks and Recreational & Open spaces \\
\hline Residential & High density residential \\
\cline { 1 - 2 } Government and Institutional & \\
\hline Resource and Industrial & Industrial \\
\hline waterbody & Water \\
\hline
\end{tabular}


The reclassification results are shown in Figures 4.6 and 4.7.

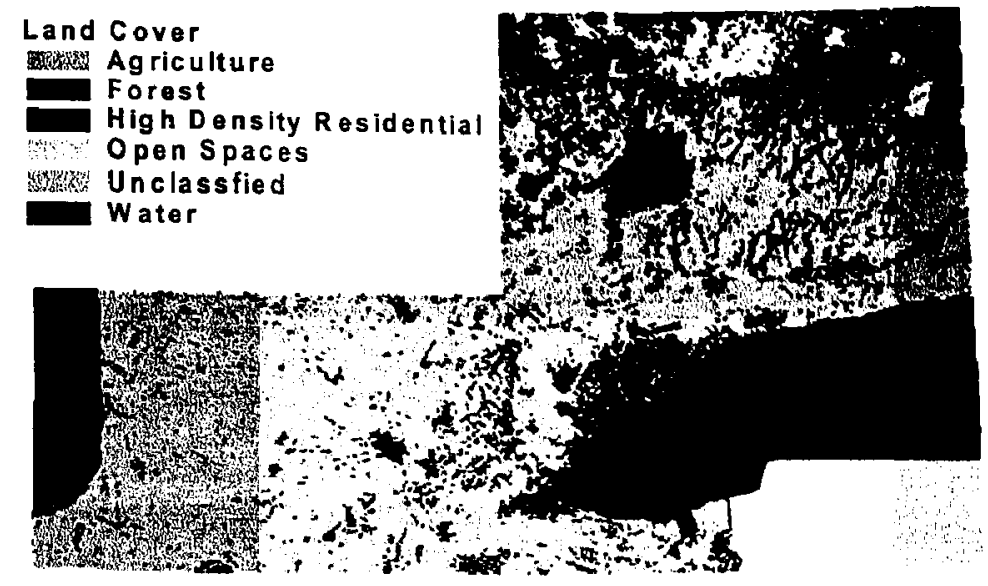

Figure 4.6 Land cover (early 1990s) classified according to the TR55

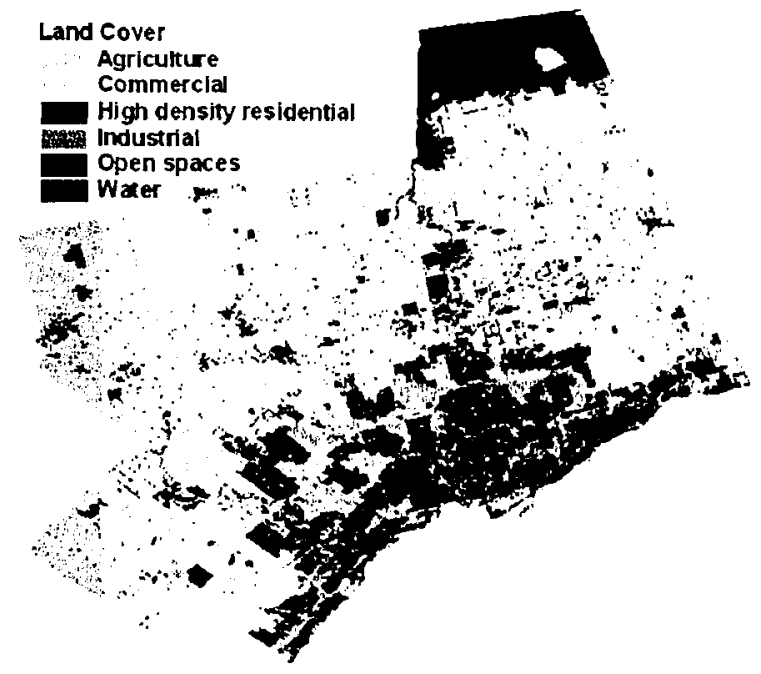

Figure 4.7 Land cover (2003) classified according to the TR55

\subsection{Watershed boundaries in the Toronto Region}

Following the steps of terrain processing in the HEC-GeoHMS, the watershed boundaries within the Toronto Region are generated. To guarantee the integrity of the results, defining suitable "the largest drainage area" is critical. If the threshold is set too small, 
the number of watersheds generated will be more than the reality and vise verse. Furthermore, because the integration ways of sub-watersheds vary with threshold value, the shapes of the final watershed are different responding to each threshold value. In this study, by trial and error method, the largest drainage area is set to 40,000 cells (a total of $56,093,680$ cells in the study area). As the resolution is $10 \mathrm{~m}$, the largest drainage area is equal to $4 \mathrm{~km}^{2}$.

The main hydrological characteristics of the watersheds in the Toronto Region are shown in the following.

\subsubsection{Flow Direction}

The flow direction has been emphasized by Marks et al.(1984), and Jenson and Dominique (1988). The flow direction for a cell is the direction in which water flows out of the cell.
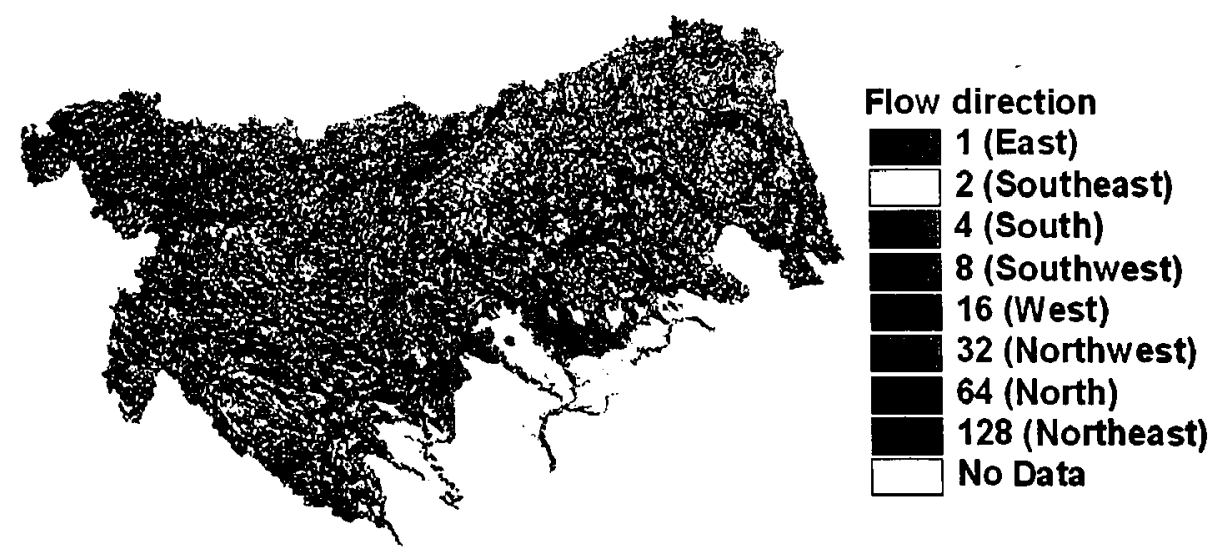

Figure 4.8 Flow direction

The streams in Etobicoke and the west part of the Humber River flow mainly to northeast, whereas the main flow direction in the west part of the Humber River is southwest. The 
streams in the Mimico Creek, as well as the south part of the Don River and Highland Creek flow to the southeast. Comparing the flow direction map with the stream map, the outline of the main streams can be figured out in the flow direction map.

\subsubsection{Flow Accumulation}

A flow accumulation is defined by O'Callaghan and Mark (1984) as an operator which gives the drainage direction matrix and a weight matrix, and determines a resulting matrix such that each element represents the sum of the weights of all elements in the matrix which drain to that element. A cell with the flow accumulation which is higher than a certain threshold will form a connected drainage network, provided that the DEM has no pots or depressions without outlet (Meijerink, et al., 1994). Figure 4.9 shows the flow accumulation within the study area. The accompanying block diagram shows the streams formed by the cells having accumulation more than $8,664,913$ cells.

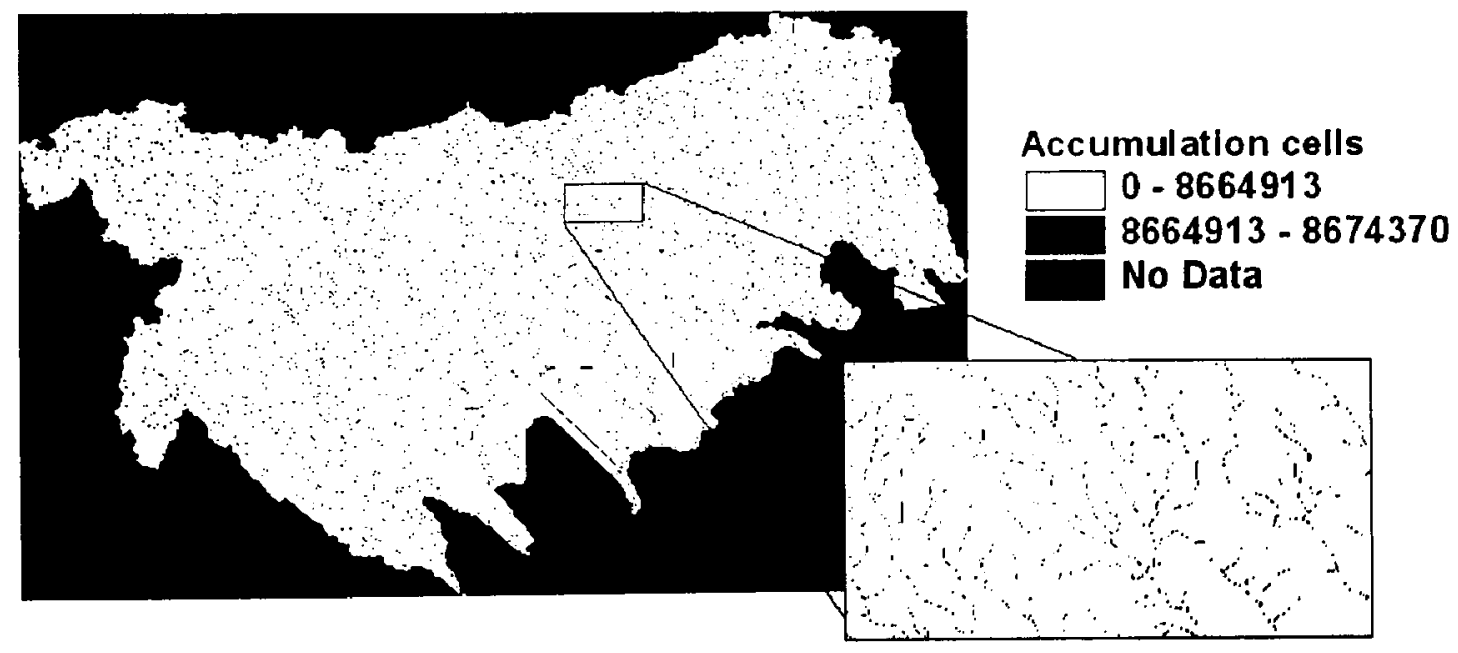

Figure 4.9 Flow accumulation in each cell 


\subsubsection{Watershed Boundaries and Streams within Toronto Region}

The final results of the watershed boundaries and the stream network are shown in Figure

4.10.

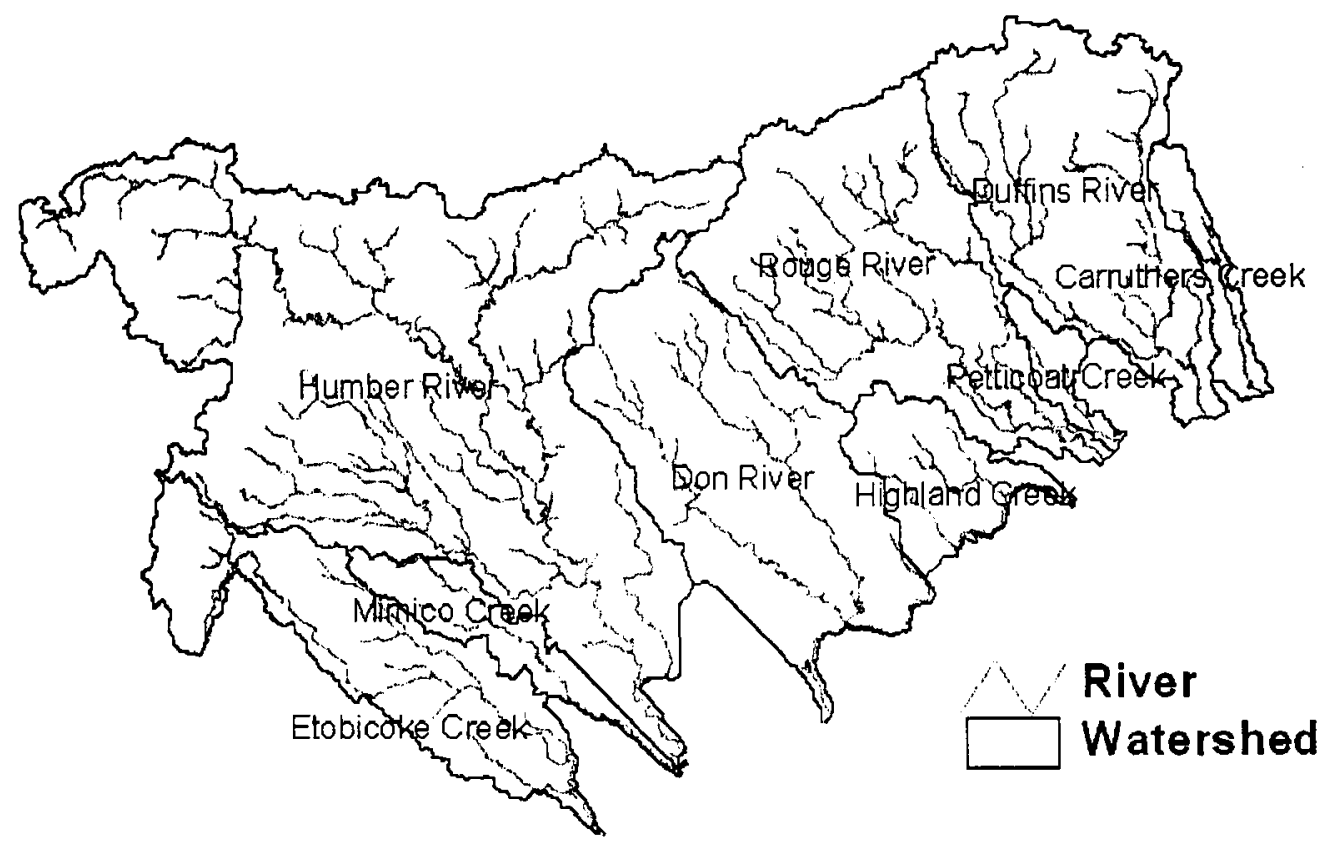

Figure 4.10 Watersheds in the Toronto Region

Since the elevation in the south part changed little, parts of the watershed boundaries are presented in straight lines, as well as some streams.

\subsubsection{Accuracy Analysis}

Comparing the watersheds generated in this project with the data from TRCA (see Figure 4.11), the shapes of the corresponding watershed are very similar. To evaluate the result numerically, the area of each watershed is calculated using Xtool extension of ArcView (see Table 4.3). 


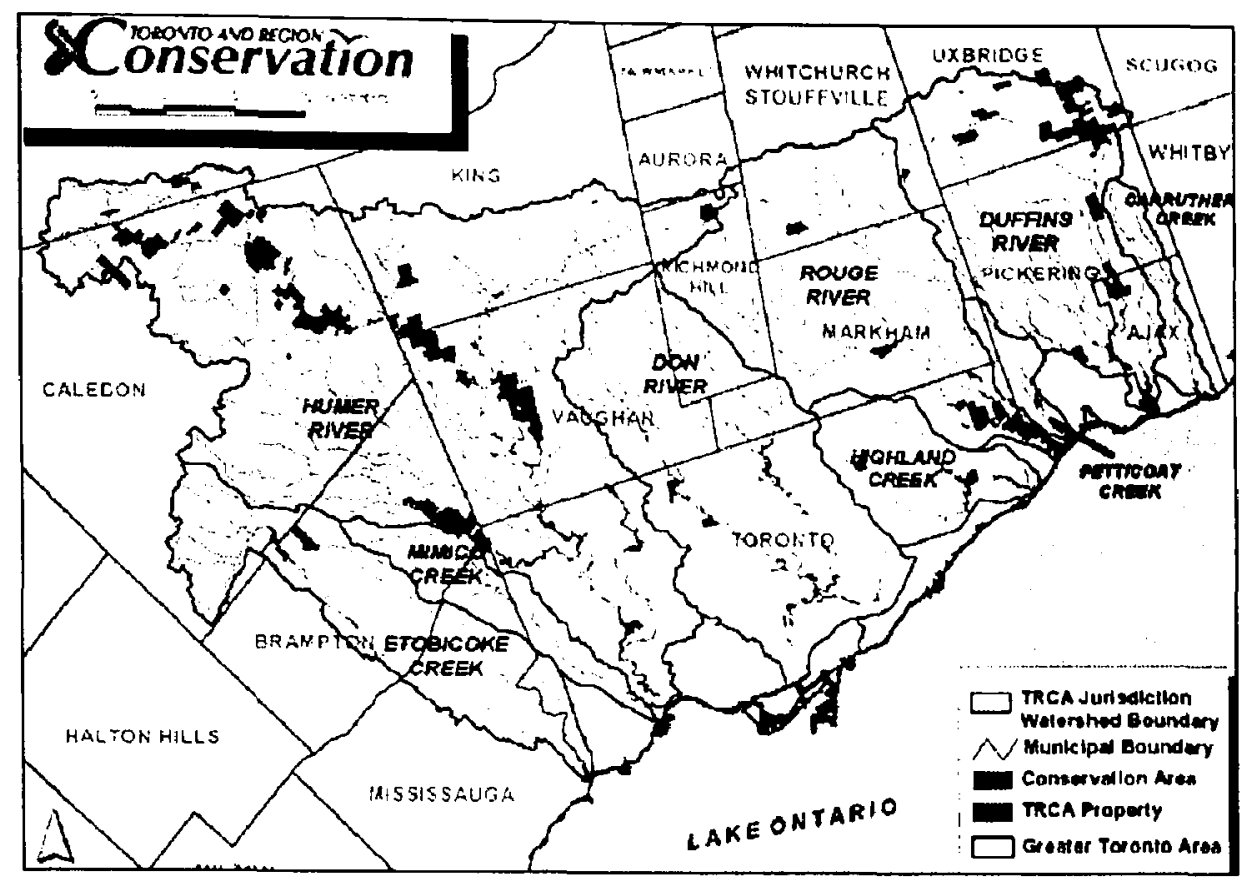

Figure 4.11 Watersheds in Toronto (From TRCA, 2004)

Table 4.3 The areas of the watersheds

\begin{tabular}{|l|c|c|}
\hline & $\begin{array}{c}\text { Data from TRCA } \\
\text { Area }\left(\mathrm{km}^{2}\right)\end{array}$ & $\begin{array}{c}\text { Calculation in this study } \\
\text { Area }\left(\mathrm{km}^{2}\right)\end{array}$ \\
\hline Etobicoke Creek & 211.65 & 207.51 \\
\hline Mimico Creek & 77.09 & 64.33 \\
\hline Humber River & 910.77 & 879.99 \\
\hline Don River & 358.06 & 326.61 \\
\hline Highland Creek & 101.58 & 85.6 \\
\hline Rouge River & 332.88 & 335.29 \\
\hline Petticoat Creek & 26.82 & 25.65 \\
\hline Duffins Creek & 286.53 & 289.87 \\
\hline Carruthers Creek & 38.13 & 38.91 \\
\hline
\end{tabular}

The area calculated by Xtool is in the unit of acres. To compare with the data obtained from TRCA, the unit has been converted to square kilometers. Only the three watersheds in the west, Carruthers Creek, Duffins Creek and Rouge River, have a bigger area than those from TRCA. The DEM (see Figure 4.2) shows that except for those three watersheds the south parts of other watersheds are very flat. Those flat parts are not 
included into the watersheds when generating watershed boundaries. This is the main reason for the difference between the data from TRCA and the results obtained in this study. This is also a general problem when delineating the boundaries of watershed from the DEM data as mention in Chapter 2.

To test if the two data sets are from the same population, SPSS software is employed to make a paired-samples $t$ test.

Table 4.4 Correlations between the paired area samples

\begin{tabular}{|l|l|l|l|l|}
\hline \multicolumn{2}{|l|}{} & N & Correlation & Sig. \\
\hline Pair 1 & TRCA \& Project & 9 & 0.999 & 0.000 \\
\hline
\end{tabular}

Table $4.5 \mathrm{t}$-test of the paired area samples

\begin{tabular}{|c|c|c|c|c|c|c|c|c|}
\hline & \multicolumn{5}{|c|}{ Paired Differences } & $t$ & df & $\underset{\substack{\text { Sig. } \\
\text { (2-tailed) }}}{ }$ \\
\hline & $\begin{array}{l}\text { Mean } \\
\left(\mathrm{km}^{2}\right)\end{array}$ & $\begin{array}{c}\text { Std. } \\
\text { Deviation }\end{array}$ & $\begin{array}{l}\text { Std. Error } \\
\text { Mean }\end{array}$ & $\begin{array}{r}95 \% \mathrm{C} \\
\text { Inter } \\
\text { Dif }\end{array}$ & $\begin{array}{l}\text { nfidence } \\
1 \text { of the } \\
\text { rence }\end{array}$ & & & \\
\hline & & & & Lower & Upper & & & \\
\hline TRCA -Project & 9.97 & 13.67 & 4.56 & -.54 & 20.48 & 2.188 & 8 & 0.060 \\
\hline
\end{tabular}

In this study, the null hypothesis is that there is NO DIFFERENCE between the data from TRCA and generated in this project, so $\mathrm{H}_{0}: \mu_{T R C A}=\mu_{\text {Project. }}$ The alternative hypothesis is $\mathrm{H}_{1}: \mu_{T R C A} \neq \mu_{\text {Project }}$

From Table 4.4, the correlation between the two data sets is 0.999 . So there is association between those two data sets. Table 4.5 is the $\mathrm{t}$ test results, noticing that $t$ is 2.188 with 8 $d f$, and the significance is listed as 0.06 . So the null hypothesis can not be rejected at the level of 0.05 . That suggests that the area for each watershed calculated from this project 
is same with the data from TRCA. It is obvious that GIS is an efficient tool for hydrological modelling. In another word, the results generated from this study are good and can be used for further watershed research.

\subsection{Comparing the Land Cover Effect on Runoff in the early 1990s with 2003}

Forsythe (2002) found there is $9.15 \mathrm{~km}^{2}$ per year average new developed land when comparing growth in the Toronto Region from 1974 to 2001 , and $10.6 \mathrm{~km}^{2}$ per year from 1999 to 2002 . To evaluate if the urban development affects the volume of runoff, the curve numbers and runoff were calculated for early 1990s and 2003.

Curve number was set to each polygon according to Table 3.4. The curve number for each watershed is calculated according to Equation (3.6).

Following the steps shown in Figure 3.6, the curve number of each watershed is calculated in both early 1990s and 2003. The results are shown in Figure 4.12. In Figure 4.12 (a), the biggest curve number in the early 1990s is 92, while in 2003 (see Figure 4.12 (b)) it is 95 . For both years, the soil is the same. So the bigger the curve number is, the bigger the area of impervious surface and the volume of runoff are. The polygons in which the colors get darker from the early 1990s to 2003 are the region where the land cover has changed from pervious to impervious surface. 

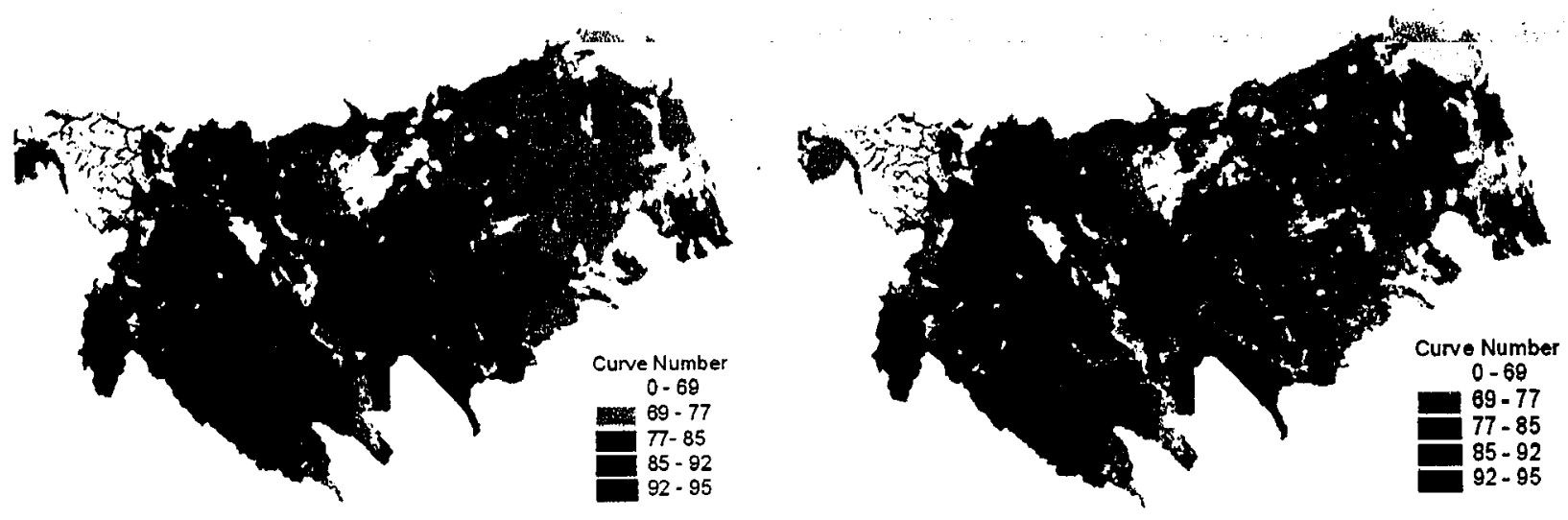

Figure 4.12 Curve numbers ( (a) in the early 1990s (b) in 2003)

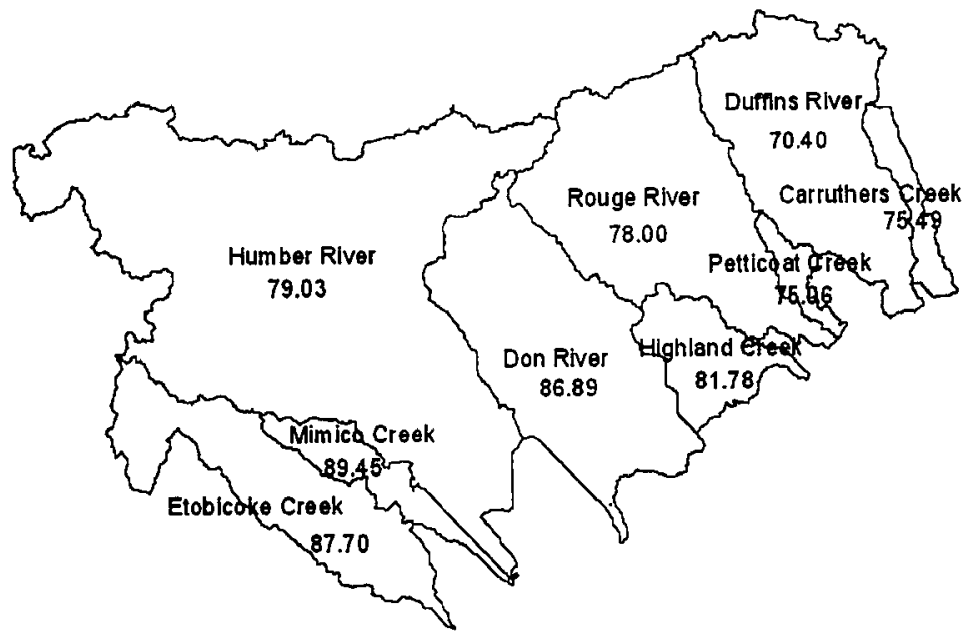

(a)

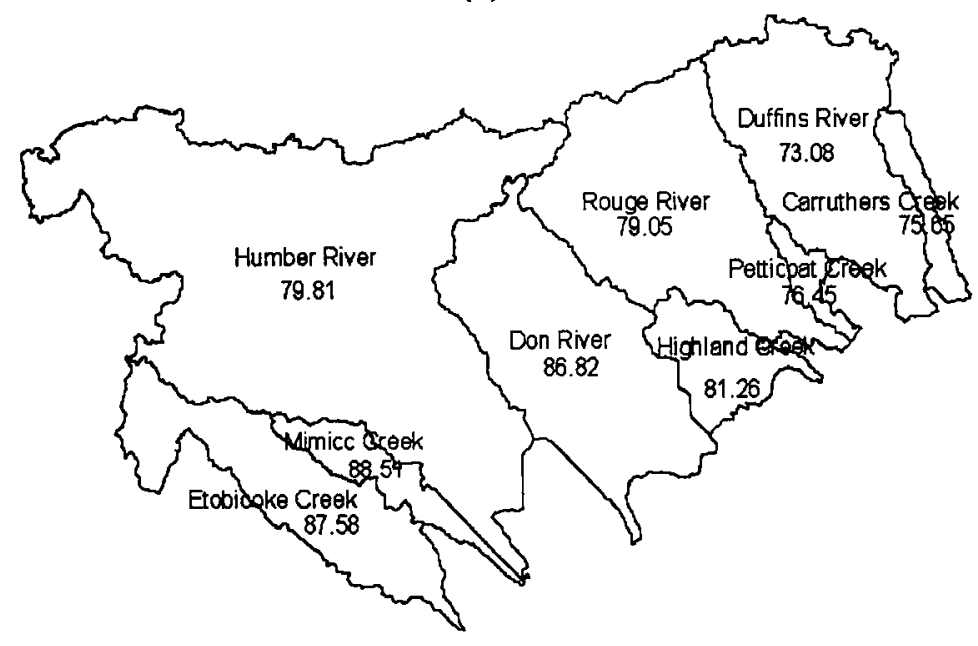

(b)

Figure 4.13 Curve numbers of each watershed ((a) in the early 1990s, (b) in 2003) 
In this study, the curve number of each watershed is more useful, since hydrological management is carried out on the watershed basis. The curve numbers in the early 1990s and 2003 are shown in Figure 4.13. It seems that there is little change of each watershed. With the help of the SPSS software, the curve numbers in two years are testified to be the same (see Tables 4.6 and 4.7), with a big significance of $22.2 \%$.

Table 4.6 Correlations between the paired curve number samples

\begin{tabular}{|l|r|r|r|r|}
\hline & Mean & N & Std. Deviation & $\begin{array}{c}\text { Std. Error } \\
\text { Mean }\end{array}$ \\
\hline Curve number early 1990s & 80.42 & 9 & 6.51 & 2.17 \\
\hline Curve number 2003 & 80.91 & 9 & 5.6 & 1.87 \\
\hline
\end{tabular}

Table 4.7 t-test of the paired curve number samples

\begin{tabular}{|c|c|c|c|c|c|c|c|c|}
\hline \multirow{3}{*}{ Pair } & \multicolumn{5}{|c|}{ Paired Differences } & \multirow[t]{2}{*}{$t$} & \multirow[t]{2}{*}{$\mathrm{df}$} & \multirow[t]{2}{*}{$\begin{array}{l}\text { Sig. (2- } \\
\text { tailed) }\end{array}$} \\
\hline & Mean & $\begin{array}{c}\text { Std. } \\
\text { Deviation }\end{array}$ & $\begin{array}{l}\text { Std. } \\
\text { Error } \\
\text { Mean }\end{array}$ & $\begin{array}{r}95 \% \mathrm{C} \\
\text { Inter } \\
\text { Dif }\end{array}$ & & & & \\
\hline & & & & Lower & Upper & & & \\
\hline $\begin{array}{l}\text { Curve number } \\
\text { early 1990s- } \\
2003\end{array}$ & -0.49 & 1.11 & .37 & -1.34 & .36 & -1.32 & 8 & 0.22 \\
\hline
\end{tabular}

Based on the results above, it can be concluded that the land cover change has little effect on the curve numbers of watershed. It is because:

1. The variation of land cover is too little to make the curve numbers different. The curve number for each watershed is weighted curve number. If the area of a polygon which has changed from pervious to impervious surface is very small, the weight for this polygon is also very small. Then the weighted curve number of watershed can not reflect the effect of land cover change very well.

2. The data sets of land cover for early 1990 s and 2003 have different classification systems. 
But the little variation of the curve numbers dose not mean the land cover change has no effect on the change of runoff. Especially when the rainfall is increasing, little change of curve number will increase runoff a lot (see Figure 4.14). So from the aspect of long term effect, the land cover change has significant influence on the volume of runoff.

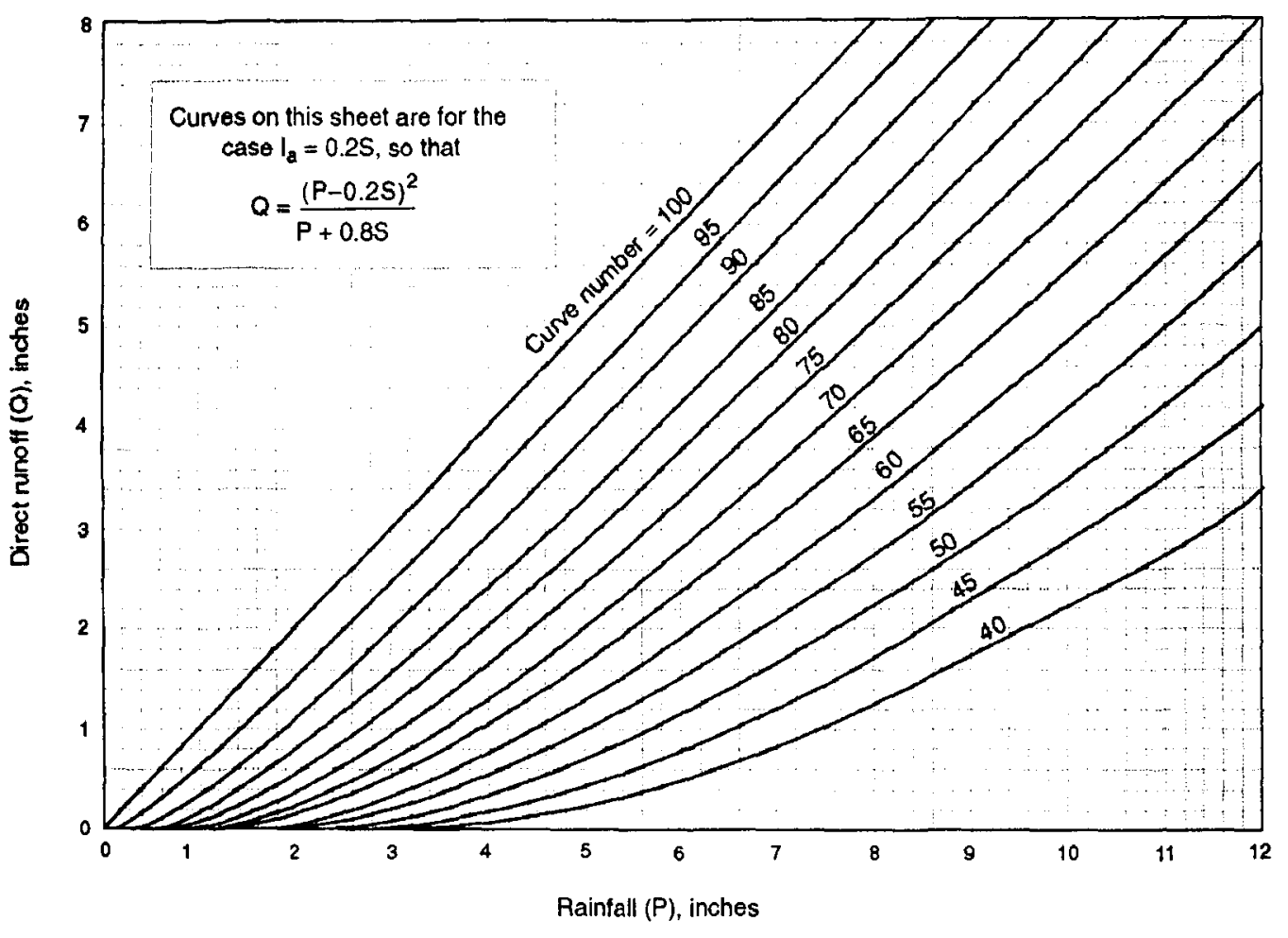

Figure 4.14 The relationship among rainfall, runoff and curve number (Technical Release,

Further comparison of curve numbers and runoff of each watershed is shown in Table 4.8. The runoff is calculated by Equations (3.4) and (3.5). During the sub-basin runoff simulation, the selected basins are assumed to be independent from each other. The simulation of a storm event over a watershed is then realized one basin at a time (Vieux, 2001). Annual rainfall in 2000, 25.04 inches (Environment Canada, 2000), was used to calculate the runoff in each watershed. 
Table 4.8 Comparison of the curve numbers and runoffs between early 1990s and 2003

\begin{tabular}{|l|c|c|c|c|c|c|}
\hline \multirow{2}{*}{ Watershed } & \multicolumn{2}{|c|}{$\begin{array}{c}\text { Curve } \\
\text { Number }\end{array}$} & \multicolumn{2}{c|}{$\begin{array}{c}\text { Runoff } \\
\text { (rainfall=25.04 inches) }\end{array}$} & \multicolumn{2}{c|}{$\begin{array}{c}\text { Difference } \\
\text { (03'-90') }\end{array}$} \\
\cline { 2 - 7 } & $\begin{array}{c}\text { early } \\
1990 \mathrm{~s}\end{array}$ & 2003 & $\begin{array}{c}\text { early } \\
1990 \mathrm{~s} \\
\left(\mathrm{~m}^{3}\right)\end{array}$ & $\begin{array}{c}2003 \\
\left(\mathrm{~m}^{3}\right)\end{array}$ & $\begin{array}{c}\text { Curve } \\
\text { number }\end{array}$ & $\begin{array}{c}\text { Runoff } \\
\left(\mathrm{m}^{3}\right)\end{array}$ \\
\hline Don River & 86.89 & 86.82 & $193,710,645$ & $193,627,685$ & -0.07 & $-82,960$ \\
\hline $\begin{array}{l}\text { Etobicoke } \\
\text { Creek }\end{array}$ & 87.7 & 87.58 & $12,365,2287$ & $123,599,579$ & -0.12 & $-52,708$ \\
\hline $\begin{array}{l}\text { Highland } \\
\text { Creek }\end{array}$ & 81.78 & 81.26 & $49,081,734$ & $48,907,840$ & -0.52 & $-173,894$ \\
\hline $\begin{array}{l}\text { Mimico } \\
\text { Creek }\end{array}$ & 89.45 & 88.51 & $38,658,752$ & $38,446,699$ & -0.94 & $-212,053$ \\
\hline $\begin{array}{l}\text { Humber } \\
\text { River }\end{array}$ & 79.03 & 79.81 & $494,729,643$ & $497,409,894$ & 0.78 & $2,680,251$ \\
\hline $\begin{array}{l}\text { Carruthers } \\
\text { Creek }\end{array}$ & 75.49 & 75.65 & $21,027,586$ & $21,254,112$ & 0.16 & 226,526 \\
\hline $\begin{array}{l}\text { Duffins } \\
\text { River }\end{array}$ & 70.40 & 73.08 & $150,093,108$ & $153,581,955$ & 2.68 & $3,488,847$ \\
\hline $\begin{array}{l}\text { Petticoat } \\
\text { Creek }\end{array}$ & 75.06 & 76.45 & $13,629,325$ & $13,768,853$ & 1.39 & 139,528 \\
\hline Rouge River & 78 & 79.05 & $186,858,269$ & $188,303,487$ & 1.05 & $1,445,218$ \\
\hline Average & & & $141,271,261$ & $142,100,012$ & 0.49 & 828,751 \\
\hline
\end{tabular}

Five out of eight watersheds experienced the increase of the curve numbers and the volume of runoff. The Duffins River has the biggest increase in curve number and the volume of runoff. While the curve number and runoff for the Mimico Creek decrease most. The runoff of the whole Toronto Region increased $828,751 \mathrm{~m}^{3}$ in 2003 comparing the runoff in the early 1990 s.

According to the TRCA (2005), the Duffins Creek and Carruthers Creek watersheds are among the healthiest in the Greater Toronto Area, and the Etobicoke and Mimico Creek watersheds are two of the most highly developed ones, and therefore degraded watersheds in the Toronto area. The citation is consistent with the results of this study. 


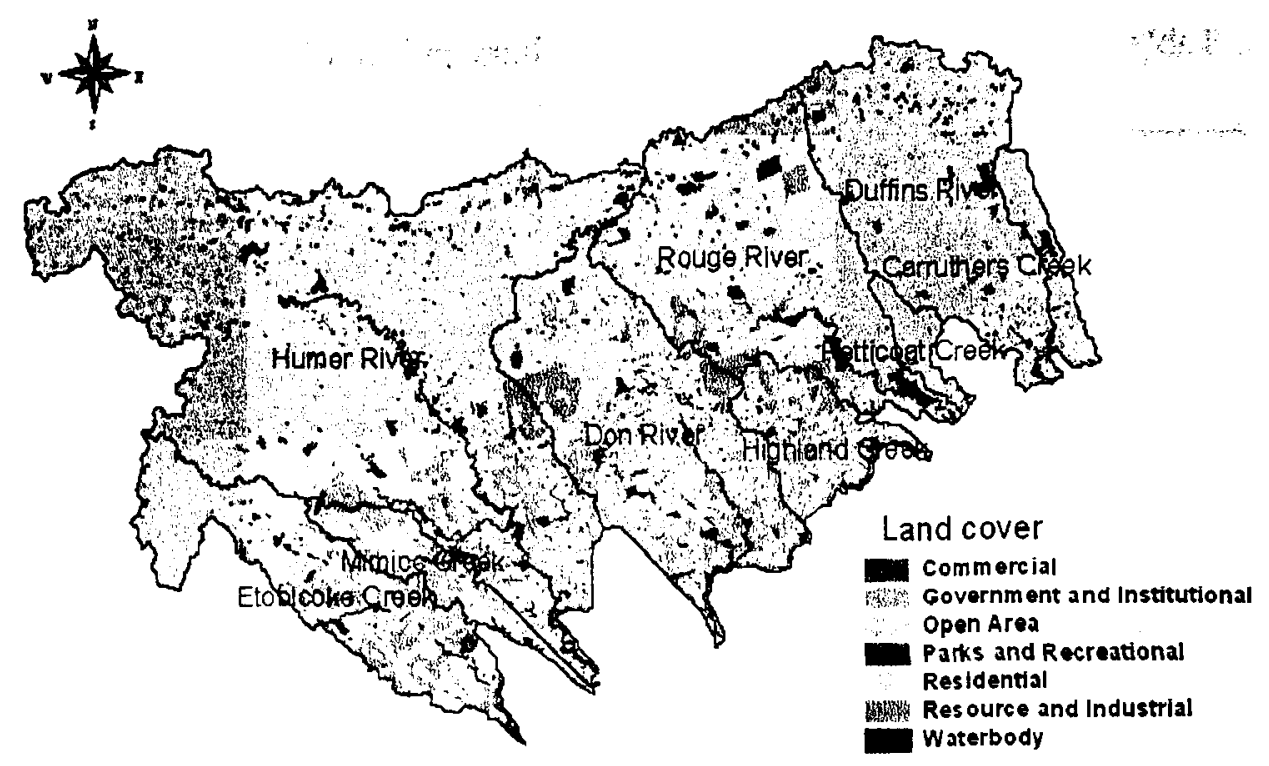

Figure 4.15 Land cover of each watershed in 2003

Figure 4.15 shows that Duffins River has the smallest impervious area, whereas almost the whole Mimico Creek is coved by residential and industrial land. There is little space to develop for the Mimico Creek watershed. So the results of this research are reasonable that the curve numbers in developed watershed have little change from the early 1990 s to 2003.

\subsection{Curve Number in the Study Area}

As mentioned before, the curve number is mainly influenced by land cover. Because of the ambiguous classification of specific land use classes in the SCS method, in theory a given user could associate any number from a range of curve numbers that would loosely correspond to a particular local land use classification scheme (Manson, 2003). Then land cover classification is vital to the accuracy of the curve number calculation. Based on two year land cover data, the classification results will approach the reality. So the curve 
numbers of 2003 were calculated again based on the both land cover information of early 1990s and 2003.

Since the curve numbers of 2003 will be calculated, the land cover data in 2003 are the main reference. By intersecting the two land cover layers in the early 1990s and 2003, the new layer is generated in which each polygon includes the land cover information in both years. The following principles are used when reclassifying land cover:

- Classification based mainly on the 2003 land cover information: commercial, government and institutional, residential. Because those land cover types represent the newly urbanized area.

- Refer to the early 1990s land cover information: Open Area. In 2003, Open Area land cover includes several kinds of the TR-55 land cover types. Agriculture, forest, sometimes even water were viewed as open areas in 2003 land cover data.

- Refer to the location and shape of polygons. Some waterbodies in the early 1990 s were classified into almost any types of land covers. By checking the shape of the polygon, waterbodies or streams can be identified easily. Location can be a very useful reference too. For example, some polygons which are classified as Open Area in 2003 land cover data are Settlement and Developed Land in the early 1990s data. By examining those polygons' locations, it was found that those polygons are either roads or parking lots, which are located adjacent to the industrial, commercial and residential land. So those polygons are classified as Parking and paved spaces.

Based on the classification principle mentioned above, the land cover data in 2003 were classified again. The classification result is shown in Table 4.9. 
Table 4.9 Classification of the land cover based on the TR-55

\begin{tabular}{|c|c|c|c|c|}
\hline $\begin{array}{c}\text { Land cover in the early } \\
1990 \mathrm{~s}\end{array}$ & Land cover in 2003 & TR-55 & $\begin{array}{c}\text { Polygon } \\
\text { count }\end{array}$ & $\begin{array}{c}\text { Area } \\
\text { (Acres) }\end{array}$ \\
\hline \multirow{7}{*}{ Agriculture } & Commercial & Commercial & 145 & 1241.674 \\
\hline & Government and Institutional & Residential & 61 & 89.9614 \\
\hline & Open Area & Agriculture & 468 & 299973.959 \\
\hline & Parks and Recreational & Open spaces & 382 & 14363.066 \\
\hline & Residential & Residential & 303 & 24956.853 \\
\hline & Resource and Industrial & Industrial & 219 & 14059.269 \\
\hline & Waterbody & Water & 2100 & 3215.228 \\
\hline \multirow{4}{*}{$\begin{array}{l}\text { Dense Coniferous } \\
\text { Forest }\end{array}$} & Open Area & Forest & 5 & 5861.323 \\
\hline & Parks and Recreational & Open spaces & 1 & 214.115 \\
\hline & Residential & Residential & 3 & 7.2470 \\
\hline & Waterbody & Water & 66 & 71.004 \\
\hline \multirow{6}{*}{$\begin{array}{l}\text { Dense Deciduous } \\
\text { Forest } \\
\end{array}$} & Government and Institutional & Residential & 4 & 327.704 \\
\hline & Open Area & Forest & 8 & 13107.619 \\
\hline & Parks and Recreational & Open spaces & 10 & 546.09 \\
\hline & Residential & Residential & 19 & 260.408 \\
\hline & Resource and Industrial & Industrial & 5 & 84.265 \\
\hline & Waterbody & Water & 102 & 209.6 \\
\hline \multirow[t]{4}{*}{ Marshes } & Open Area & Open spaces & 5 & 203.4920 \\
\hline & Parks and Recreational & Open spaces & 1 & 10.447 \\
\hline & Residential & Residential & 2 & 14.521 \\
\hline & Waterbody & Water & 6 & 110.161 \\
\hline \multirow{4}{*}{$\begin{array}{l}\text { Mine Tailings, } \\
\text { Quarries, Bedrock } \\
\text { Outcrop, Mud Flats }\end{array}$} & Open Area & Open spaces & 1 & 374.159 \\
\hline & Residential & Residential & 1 & 0.317 \\
\hline & Resource and Industrial & Industrial & 3 & 21.582 \\
\hline & waterbody & Water & 5 & 19.693 \\
\hline \multirow[t]{4}{*}{ Mixed Forest } & Open Area & Forest & 2 & 1303.242 \\
\hline & Parks and Recreational & Open spaces & 1 & 48.806 \\
\hline & Residential & Residential & 2 & 12.813 \\
\hline & Waterbody & Water & 5 & 4.388 \\
\hline \multirow{7}{*}{$\begin{array}{l}\text { Settlement and } \\
\text { Developed Land }\end{array}$} & Commercial & Commercial & 1262 & 4124.764 \\
\hline & Government and Institutional & Residential & 444 & 11317.446 \\
\hline & Open Area & $\begin{array}{l}\text { Parking and paved } \\
\text { spaces }\end{array}$ & 813 & 20395.277 \\
\hline & Parks and Recreational & Open spaces & 826 & 11280.75 \\
\hline & Residential & Residential & 403 & 82738.63 \\
\hline & Resource and Industrial & Industrial & 668 & 38595.92 \\
\hline & Waterbody & Water & 133 & 520.6 \\
\hline \multirow[t]{4}{*}{ Treed Wetlands } & Open Area & Forest & 4 & 136.364 \\
\hline & Parks and Recreational & Open spaces & 5 & 236.695 \\
\hline & Residential & Residential & 3 & 16.529 \\
\hline & waterbody & Water & 1 & 14.188 \\
\hline \multirow[t]{5}{*}{ Water } & Open Area & Water & 8 & 40.968 \\
\hline & Parks and Recreational & Open spaces & 2 & 12.239 \\
\hline & Residential & Residential & 2 & 1.08 \\
\hline & Resource and Industrial & Water & 1 & 2.47 \\
\hline & Waterbody & Water & 14 & 85.363 \\
\hline
\end{tabular}




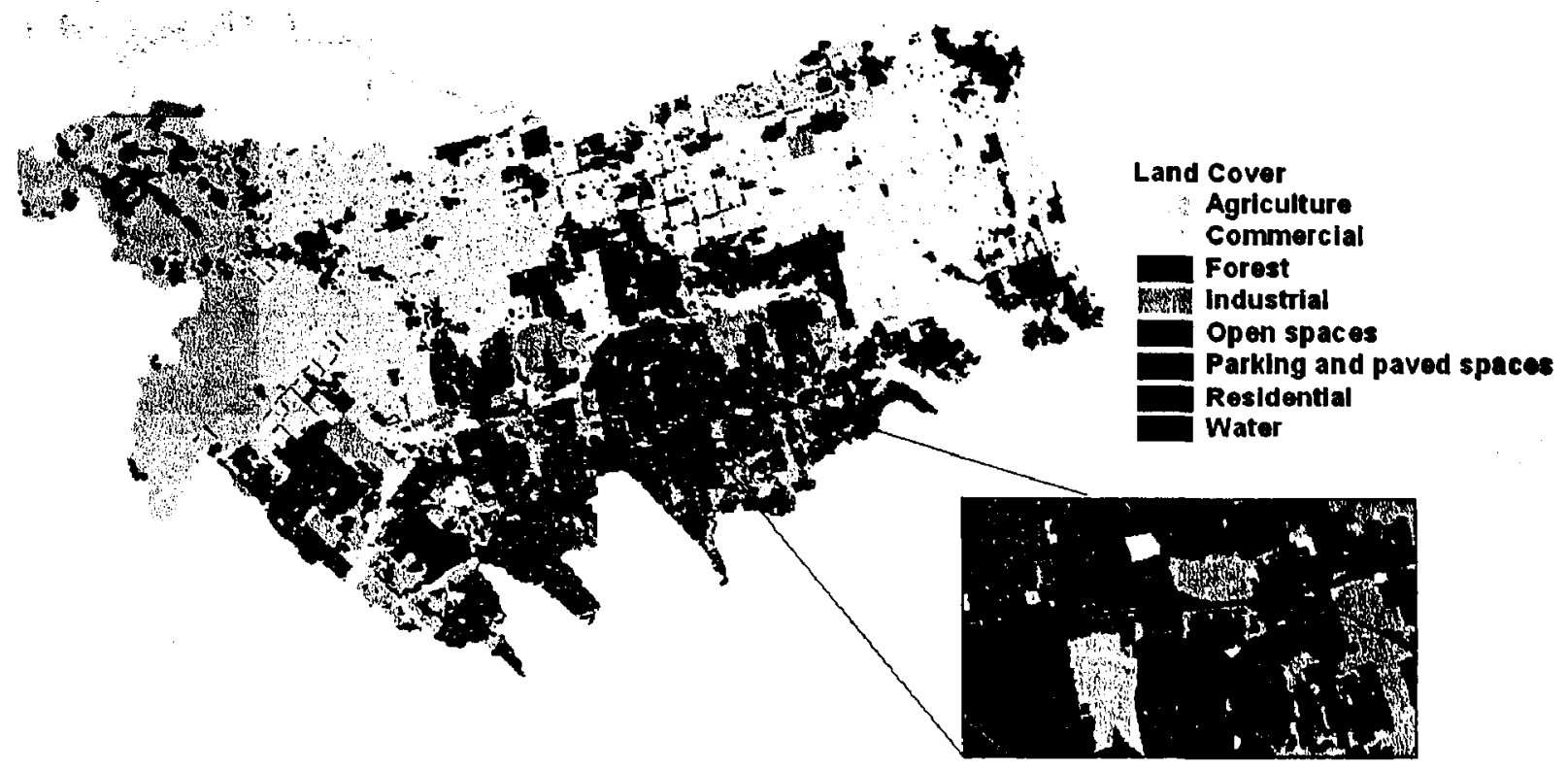

Figure 4.16 Land cover classified based on the information of early 1990s and 2003

The final land cover is shown in Figure 4.16. Obviously, it is more accordant with the reality. For example the open spaces distribute along the streams; residential, industry, commercial and residential lands are concentrated together; the roads in the developed area are presented in the shape of belt; and numerous waterbodies are distributed randomly.

The curve numbers for 2003 are calculated again based on the land cover classification as mentioned in Table 4.9. The results are shown in Figure 4.17. In the research of Manson (2003), the curve number for the Duffins River is 71.5 after calibration, which is similar with the result in this study (70.48). The curve number for the whole Toronto Region is 80.4 . 


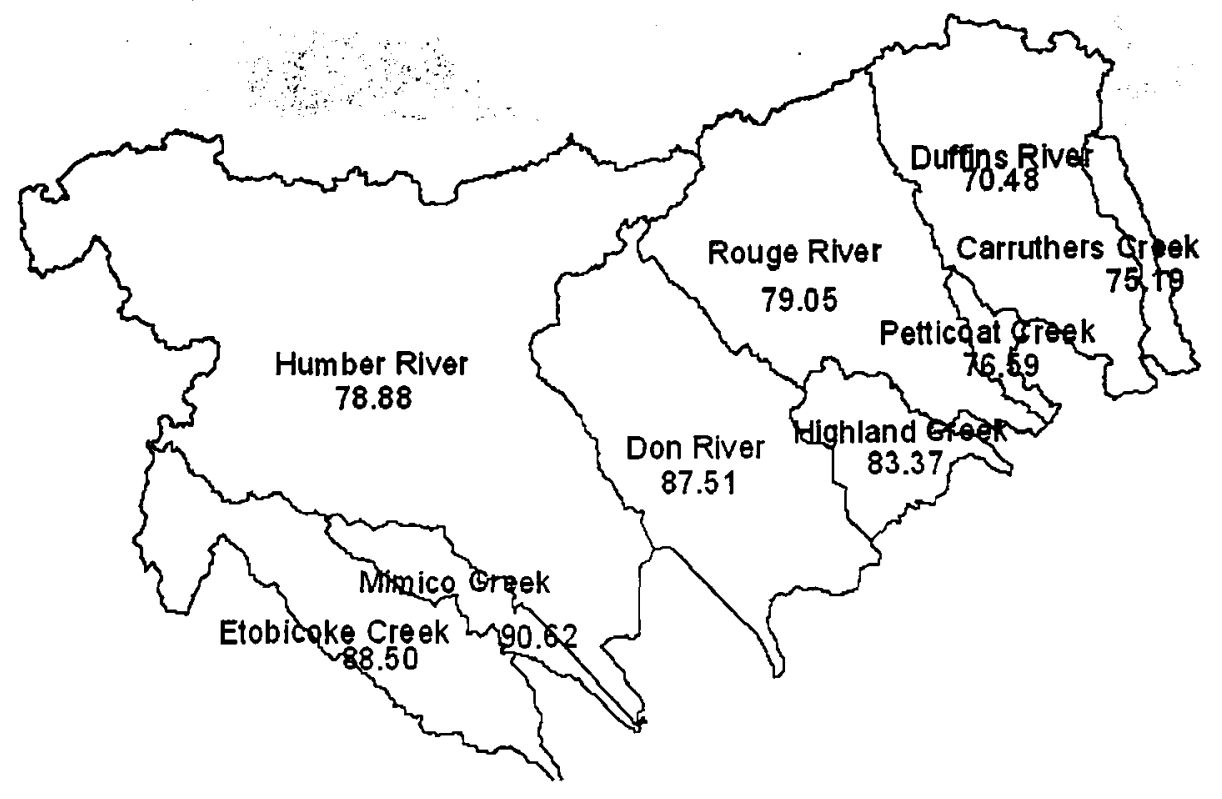

Figure 4.17 Curve numbers in the Toronto Region (2003)

After eliminating the effect of the vagueness of the land cover classification, the curve numbers are more reliable and can be used to estimate the runoff of the each watershed in the Toronto Region.

The curve numbers of the watersheds in the Toronto Region are relatively high, changing from 70.48 (Duffines River) to 90.62 ( Mimico Creek). 


\section{Chapter 5}

\section{CONCLUSIONS AND RECOMMENDATIONS}

The goal of this study was to extract the hydrological characteristics of the Toronto Region, Ontario, from the DEM data. Combining with other spatial data, those hydrological parameters are used to calculate the runoff for two years. Results have shown that watersheds generated from the DEM data are good enough for practical usage.

Comparing the curve numbers of each watershed in the early 1990s and 2003, there is small variation. So it can be said the land cover change has little effect on the curve number on the watershed level. One reason for this result is that the land cover in two years varies too little to make the curve number weight different. The weight is a necessary parameter to calculate the curve number for each watershed. At the same time, the data sets of land cover for early 1990s and 2003 have different classification systems. This may be another reason for the little change in curve numbers. But this does not mean urbanization has little effect on the change of runoff since there was pervious surface changing to the impervious surface. By referring the land cover in 2003 and early 1990s, the curve numbers are calculated again for 2003 . Since the uncertainty resulting from the land cover classification is eliminated, the curve numbers in 2003 can be used to calculate the runoff in the Toronto Region.

The watersheds in the Toronto Region have a relatively high curve numbers, which means that more stormwater will become runoff. The City of Toronto should balance its 
development and the conservation of watersheds, especially for those healthier watersheds. For example, the Duffins Creek is viewed as one of the healthiest watersheds in the GTA (TRCA, 2004). But its curve number increased most from early 1990s to 2003. This is because it has more space to develop impervious surface, such as residential or commercial lands.

The spatial data generated from this study can be applied to many other hydrological models, such as calculating the peak discharge, sediment volume, hydrograph, etc. Future study can use the data generated from this research to understand other hydrological processes in the Toronto Region.

For a big watershed like in the Toronto Region, it takes a long time to generate watershed boundaries from the DEM data. In this study, the raster DEM data used to generate watershed boundary has 6553 rows and 8560 columns, with the resolution of $10 \mathrm{~m}$. It took almost one week to finish all the calculations. In the future, some new algorithm can be developed to speed up the calculations, such as using the TIN to generate watershed boundaries. 


\section{REFERENCES}

Band, L.E., 1986. Topographic partition of watersheds with digital elevation models, Water Resources Research, 22(1): 15-24.

Beasley D.B., L.F. Huggins and E.J. Monke, 1982. Modelling sediment yields from agriculture watersheds. Journal of Soil and Water Conservations, 37(2):113-117.

Beven, K. and M. Kirkby. 1979. A physically-based variable contributing area model of basin hydrology. Hydrological Sciences Journal, 24(1):43-69.

Bhaduri, B., M. Grove, C. Lowry and J. Harbor, 1997. Assessing long-term hydrologic effects of land use change. Journal of the American Water Works Association, 89(11): 94-106.

Brady L. M., F. Gray, M. Castaneda, M. Bultman and K.S. Bolm, 2001, Critical U.S.Mexico Borderland Watershed Analysis, Twin Cities Area Of Nogales, Arizona And Nogales, Sonora, URL: http://gis.esri.com/library/userconf/proc01/professional/papers/pap1006/p1006.htm ESRI, Library (last date accessed: 5 December 2004).

Brakensiek, D.L. and W.J. Rawls. 1983. Green-Ampt infiltration model parameters for hydrologic classification of soils, Advances in Irrigation and Drainage Surviving 
External Pressures (Borrelli, J., editor). American Society of Civil Engineers, New York, USA, pp.226-233.

Chairat S. and J.W. Delleur, 1993. Integrating a physical model with GRASS. Proceedings of HydroGIS 93: Application of Geographic Information Systems in Hydrology and Water Resources Management, No.211, 19-22 April 1993, Vienna, Austria, pp.143-150.

Chou, V.T., D.R. Maidment and L.W. Mays, 1988. Applied Hydrology, McGraw-Hill, City Country., 572 p.

City of Toronto, 2004, Toronto's Water Pollution Solution, URL: http://www.city.toronto.on.ca/water/protecting_quality/wwfmmp/, City of Toronto, (last date accessed: 26 December 2004).

Correia, F. N., M. G. Saraiva, and I. Ramos, 1997. GIS-Based Flood Analysis and Floodplain Management, submitted to publication in Water Resource Management, Kluwer Academic Publishers, Dordrecht, Netherlands.

Correia, F.N, F.C. Rego, M.D. Saraiva and I. Ramos, 1998. Coupling GIS with hydrologic and hydraulic flood modelling, Water Resources Management, 12 (3): 229-249. 
Department of Watershed Management, Arlington, Virginia, 2004 URL: http://www.co.arlington.va.us/departments/EnvironmentalServices/epo/Environmenta 1ServicesEpoWpover.aspx, Arlington, Virginia, (last date accessed: 15 December, 2004).

DeVautier, B.A. and A.D. Feldman, 1993. Review of GIS applications in hydrologic modelling, Journal of Water Resources Planning and Management. 119(2): 246-261.

Dikau, R. 1989, The application of a digital relief model to landform analysis in geomorphology. Three dimensional applications of Geographic Information Systems (Bonnett, R., editor), Taylor \& Francis, London, pp.55-77.

DMTI Spatial Inc. ,2003, CanMap RouteLogistics 7.2.

Environment Canada, 2000, Canadian daily climate data, temperature and precipitation. Eastern Canada, CD-ROM.

Environment Canada, 2001, RAP (Remedial Action Plans) Development/History, URL:http://www.on.ec.gc.ca/water/raps/toronto/develope e.html, Environment Canada (last date accessed: 21 December 2004). 
ET Spatial Techniques, 2004. Resources, http://www.ian-

ko.com/resources/triangulated_irregular_network.htm, ET Spatial Techniques, USA. (last date accessed: 21 December, 2004)

Forney W., L. Richards, K.D. Adams, T.B. Minor, T.G. Rowe, J.L. Smith and C.G. Raumann, 2001. Land Use Change and Effects on Water Quality and Ecosystem Health in the Lake Tahoe Basin, USGS Open-File Report 01-418, Nevada and California, $29 \mathrm{p}$.

Forsythe, K.W., 2002. Urban development in Calgary, Toronto, and Vancouver: Interpretation of Landsat data, Proceedings of the 14th Symposium for Applied Geographic Information Processing, XIV, AGIT 2002. July 3-5, 2002, Salzburg, Austria, pp.105-110.

Forsythe, K.W., 2004. Pansharpened Landsat 7 Imagery for Improved Urban Area Classification, Geomatica, 58(1): 23-31.

Frey C., 2004. What does GIS Bring to Hydrologic Modelling, URL: http://geosun.sjsu.edu/paula/285/285/cf_sem.htm\#Hydrologic_modeling, SJSU Geology Department, San José State University (last date accessed: 21 November 2004).

Garbrecht J. and L.W. Martz, 1997. The assignment of drainage direction over flat surfaces in raster digital elevation models, Journal of Hydrology, 193 (1-4):204-213. 
GeoGratis. Ontario Land Cover Data, 2004.

URL:http://geogratis.cgdi.gc.ca/clf/en?action=entrySummary\&entryId=8535\&entryT ype=productCollection\&keymap $=$ outlineCanada, Natural Resources Canada (last date accessed: 11 December 2004).

Goodchild M. F., 2001. Spatial analysis and GIS, Proceeding of the Pre-Conference Seminar of 2001 ESRI User Conference, July 8, 2001, San Diego, California, URL: http://www.csiss.org/learning_resources/content/good_sa/, Center for Spatially Integrated Social Science, University of California (last date accessed: 11 January, 2005).

Gumbo,B., N. Munyamba, G. Sithole and H.H.G. Savenihe, 2001. Coupling of Digital Elevation Model and Rainfall-Runoff Model in Storm Drainage Network Design, Proceedings of the 2nd WARFSA/WaterNet Symposium: Integrated Water Resources Management: Theory, Practice, Cases, 30-31 October 2001, Cape Town.

Hellwegger, F.L. and D.R. Maidment, 1999. Definition and connection of hydrologic elements using geographic data, Journal of Hydrologic Engineering. 2(1):10-18.

Integrated Environmental Planning Division, 2004. White Paper on Watershed-based Source Protection Planning, Strategic Policy Branch, Ministry of the Environment, Ontario. 
Jenson S.K. and J.O. Dominique, 1988. Extracting topographic structure from digital elevation data for geographic information system analysis, Photogrammetric Engineering and Remote Sensing, 54 (11):1593-1600.

King, K.W., J.G. Arnold and R.L. Bingner, 2004. Comparison of Green-Ampt and Curve Number Methods on Goodwin Creek Watershed Using SWAT, URL: http://www.ag.ohio-state.edu/ usdasdru/Staff/King/asae228j.pdf, Ohio State University (last date accessed: 30 December 2004).

Knisel, W.G. (Editor), 1980. CREAMS: a field-scale model for chemicals, runoff and erosion from agricultural management systems. Conservation Research Report No. 26, South East Area, U.S., Washington, D.C.

Kopp, S. M., 1996. Linking GIS and hydrological models: where we have been, where we are going? Proceedings of the HydroGIS'96 Conference, April 1996, Vienna, Austria, No. 235, pp. 133-139.

Leonard, R.A., W.G. Knisel, and D.A. Still, 1986. GLEAMS: groundwater loading effects of agricultural management systems, ASAE Paper No. 86-2511, Chicago.

Maidment, D.R., 1996. GIS and Hydrologic Modeling - an Assessment of Progress, Proceedings of The Third International Conference on GIS and Environmental Modeling, 22-26 January 1996, Santa Fe, New Mexico. 
Males, R. M. and W. M. Grayman, 1992. Past, Present and Future of Geographic Information Systems, Water Resources, no. 87. The Universities Council on Water Resources, pp. 5-11.

Manson, H. R., 2003. Uncertainty and sensitivity analysis of GIS based continuous hydrological modelling, M.A.Sc. Thesis., Ryerson University, Toronto, Ontario,127 p.

Mark, D.M., 1988. Network models in geomorphology, Modelling Geomorphological Systems ( Anderson, M.G., editor), Wiley, London, pp.73-79.

Marks, D., J. Dozier and J. Frew, 1984. Automated basin delineation from digital elevation data, GeoProcessing, 2 (4):299-311.

Marshall E. J., 1990, Symposium Proceedings on Urban Hydrology, American Water Resources Association, 4-8 November 1990, Denver, Colorado. 339 p.

Maune, D.F., 2001. Digital Elevation Model Technologies and Applications: the DEM Users Manual, American Society for Photogrammetry and Remote Sensing, Bethesda, Maryland, $539 \mathrm{p}$.

McClintock, K.A., J.M. Harbor and T.P. Wilson, 1995. Assessing the hydrological impact of land use change in wetland watersheds: a case study from Northern Ohio, USA, Geomorphology and Land Management in a Changing Environment (McGregor, D.F.M and D.A. Thompson, editors), Wiley and Sons, pp. 107-119. 
Meijerink, A.M.J., H.A.M. Brouwer, C.M. Mannaerts and C.R. Valenzuela, 1994, Introduction to the Use of Geographic Information Systems for Practical Hydrology, International Institute for Aerospace Survey and Earth Sciences (ITC), Enschede, Netherlands, $234 \mathrm{p}$.

Moore, I. D., 1996. Hydrologic-modelling and GIS. GIS and Environmental Modelling: Progress and Research Issues (Goodchild, M. F., L.T. Steyaert and B.O. Parks, editors ). Fort Collins, Colombia, pp. 143-148.

Moore, I. D., G.J. Burch and D.H. MacKenzie, 1988. Topographic effects on the distribution of surface soil water and the location of ephemeral gullies. Transactions of the American Society of Agriculture Engineers, 31(4): 1098-1 107.

Moore, I. D., R. B. Grayson, and A. R. Ladson, 1991. Digital terrain modelling: a review of hydrological, geomorphological and biological applications. Hydrological Processes, 5 (1): 3-30.

Moore, I.D., J.C. Gallant and L. Guerra, 1993. Modelling the spatial variablity of hydrological process using GIS, Proceedings of HydroGIS 93: Application of Geographic Information Systems in Hydrology and Water Resources Management, No.211,19-22 April 1993, Vienna Austria, pp.161-169.

Moore, I.D., R.B. Grayson and A.R. Ladson, 1991. Digital Terrain Modelling: A Review of Hydrological, Geomorphological, and Biological Applications, Hydrological Processes, 5(1):3-30. 
Moore, I.D. and J. L. Nieber, 1989. Landscape assessment of soil erosion and nonpoint source pollution, Journal of the Minnesota Academy of Science. 55(1):18-25.

National Soil DataBaes (NSDB), Canada, 2004. URL: http://sis.agr.gc.ca/cansis/nsdb/detailed/on/zipfiles.html, Canadian Soil Information System, Agriculture and Agri-Food Canada (last data accessed: 10 November, 2004).

O'Callaghan, J.F. and D.M. Mark, 1984. The extraction of drainage networks from digital elevation data, Computer Vision, Graphics, and Image Processing , 28(3), 323-344.

Ontario Genweb, 2004. URL: http://www.rootsweb.com/ canon/locator/pdontmap.html OntarioGenWeb (last date accessed: 29 December 2004)

Oweis, I.S. and R.P.Hkera, 1998. Geotechnology of Waste Management, 2nd edition, PWS Publishing Company, Boston, MA. 472 p.

Perrone J. and C.A. Madramootoo, 1998. Improved curve number selection for runoff prediction, Canadian Journal of Civil Engineering. 25 (4): 728-734.

Peucker, T.K. and D.H. Douglas, 1975. Detection of surface specific points by local parallel processing of discrete terrain elevation data, Computer vision, Graphics and Image Processing, 4 (3):375-387.

Urban Development Services Department, Toronto, 2003. Profile Toronto, No.1, URL: http://www.city.toronto.on.ca/demographics/pdf/profile tor bulletin.pdf, City of Toronto (last data accessed: 15 October 2004). 
Purdue Research Foundation, West Lafayette, Indiana, 2004. SCS Curve Number Method, URL: http://www.ecn.purdue.edu/runoff/documentation/scs.htm, Purdue University (last data accessed: 18 December 2004).

Quinn, P.F., K.J. Beven, P. Chevallier and O. Planchon, 1991. The prediction of hillslope flow paths for distributed hydrological modelling using digital terrain models, Hydrological Processes, 5 (1):59-79.

Quinn, P.F., K.J. Beven, and R. Lamb, 1995, The $\operatorname{In}(\alpha / \tan \beta)$ index: how to calculate it and how to use it within the TOPMODEL framework. Hydrological Processes, 9 (2):161-182.

Romanowicz R., J. Beven, J. Freer and R. Moore, 1993. TOPmodel as an application module within WIS. Proceeding of Hydrogis '93: Application of GIS in hydrology and water resources. 19-22 April 1993, Vienna Austria, IAHS publication, pp.211-223.

Rosenfeld A and A.C. Kak, 1982. Digital Picture Processing, Volume 2, Academic Press, New York, 349p.

Shamsi, U. M., 2002. GIS Tools for Water, Wastewater, and Stormwater Systems, American Society of Civil Engineers, Reston, Virginia. 375p.

Singh, V.P., 1995. Computer Models of Watershed Hydrology, Water Resources . Publications, Highlands Ranch, Colorado., 1130p. 
Skidmore, A.K. 1990. Terrain position as mapped from a gridded digital elevation model, International Journal of Geographical Information Systems, 4(1):33-49.

Soil Conservation Service, U.S. Department of Agriculture, 1972. Hydrology. National Engineering Handbook. Washington, D.C. pp. 10.5-10.6.

Soil Conservation Service, U.S. Department of Agriculture, 1982. Structure Site Analysis Computer Program DAMS2 (Interim Version). SCS Technical Release 48. Washington, DC.

Soil Conservation Service, U.S. Department of Agriculture, 1983. Computer Program for Project Formulation-Hydrology. SCS Technical Release 20. Washington, DC.

Soil Conservation Service, U.S. Department of Agriculture, 1985. National Engineering Handbook. Section 4.

Sui D.Z. and R.C. Maggio, 1999. Integrating GIS with hydrological modelling: practices, problems and prospects. Computers Environment and Urban Systems, 23 (1): 33-51.

Tan, C.H., A.M. Melesse and S.S. Yeh, 2002. Remote Sensing and Geographic information system in Runoff Coefficient Estimation in China Taipei. Proceeding of the 23rd Asian Conference on Remote Sensing, 25 - 29 November 2002, Kathmandu, Nepal. 
Technical Release 55 (TR-55), 1986. Urban hydrology for small watersheds, United States department of Agriculture, Nature Resources Conservation Service, Conservation Engineering Division.

The Hydrologic Engineering Center, 2003. Geospatial Hydrologic Modelling (HECGeoHMS) User's Manual, US Army Corps of Engineers.

TRCA, 2004. Protecting our water, URL: http://www.trca.on.ca/water_protection/ Toronto and Region Conservation Authority, Toronto, Ontario (last data accessed: 3 January, 2005)

VerWest J., 2002. Hydrologic Analysis in Flat Terrain, URL:

http://ceprofs.tamu.edu/folivera/TxAgGIS/Spring2002/verwest/verwest.htm

Department of Civil Engineering, Texas A\&M University (last data accessed 8 January 2005).

Vieux, B. E., 2001. Distributed Hydrologic Modeling Using GIS, Kluwer Academic Publishers, Dordrecht, Boston, 293p.

Wilson J.P., P.L. Repetto and R.D. Snyder, 2000. Effect of data source, grid resolution, and flow-routing method on computed topographic attributes, Terrain Analysis: Principles and Applications (Wilson J.P. and J.C. Gallant, editors), Wiley, New York, pp.133-161. 
Wilson, J. P. and J.C. Gallant, 2000, Terrain Analysis: Principles and Applications, Wiley, New York, 479p.

Wolock, D.M. and C.V. Prices,1994. Effects of Digital Elevation Map Scale and Data Resolution on a Topographically-Based Watershed Model. Water Resources Research, 30(11):3041-3052.

Young R.A., C.A. Onstad, D.D. Bosch and W.P. Anderson, 1987. AgNPS: Agriculture non-point-source pollution model: a watershed analysis tool, USDA-ARS, Conservation research report 35 .

Zhang, W.H., and D.R. Montgomery, 1994, Digital elevation model grid size, landscape representation, and hydrologic simulations, Water Resources Research, 30(4): 10191028. 